\title{
Prehistorik Çağlardan Doğu Roma Dönemi Sonuna Kadar Kastamonu Kentinin Kültürel Tabakalaşması
}

\section{The Cultural Stratification of Kastamonu City from Prehistoric Ages to the End of the East Roman Period}

\section{Murat KARASALİHOĞLU *}

$\ddot{O}_{z:}$ Kastamonu il merkezi, bölgesiyle birlikte tarihi akışı içinde araştırma sayısının az olmasından dolayı kültürel tabaklaşması hakkında az bilginin olduğu bir yerleşimdir. Bu saptama özellikle kentin arkeolojisini ilgilendiren Prehistorik çağlardan Geç Antik Çağ'a uzanan zaman dilimi için daha da geçerlidir. Arkeolojik veriler açısından incelendiğinde her ne kadar az ama yine de görece güçlü kanıtlar olmasına karşın MS 13. yüzyıl ikinci yarısından sonra oluşan ve günümüze gelen kent yapısının önceki aşamaları bilinmemektedir. Bu çalışmada, arkeolojik verilerle Kastamonu'nun Prehistorik cağlardan başlayarak kültürel ve kentsel tabakalaşmasına bakılmaya çalışılmıştır. Bunu yaparken coğrafi sınırlandırma olarak da Kastamonu il merkezinin MS 20. yüzyıl başına kadar koruna gelen tarihsel çekirdeği değerlendirme içine alınmıştır. Çalışma alanında arkeolojik kazıların varlığından yoksun olmasından dolayı Prehistorik çağlardan Demir Çağı'na kadar olan süreçte sadece arkeolojik yüzey araştırması bulguları değerlendirmiştir. Sonraki dönemler için ise kaya mezarları ve çevrelerindeki arkeolojik bulgular eklenmiştir. Son bölümde ise kentteki nadir Doğu Roma Dönemi yapılarından olan bir sura ait olabilecek parça üzerinde durulmuştur. Bu dönem için, Kastamonu'da bir kent surunun varlığı arkeolojik materyalle ilk kez literatüre sunulmuştur. Sonuç olarak, Geç Demir Çağı ile birlikte arkeolojik verilerin artmasıyla, MS 13. yüzyıla ulaşan yerleşimin kültürel katmanlaşması ve çağlar içindeki yerleşim tipolojisinin belirlenmesi amaçlanmıştır.

Anahtar sözcükler: Kastamonu, Kentleşme, Paphlagonia, Sasani, Arap, Doğu Roma

\begin{abstract}
Kastamonu city center is a settlement which we have little information about its cultural stratification because of few number of studies conducted on its own and its region throughout the history. This determination is especially valid for the time period lasting from Prehistoric Ages to Late Antique Age that is relevant to the archeology of the city. Although there are few but relatively strong evidence regarding the archeological data, the former phases of the city's structure which is established after the second half of $13^{\text {th }}$ century $\mathrm{AD}$ and has been existent up to present are unknown. The purpose of this study is examine the cultural and urban stratification of Kastamonu starting from Prehistoric ages by considering the archeological data. In this evaluation study, the historical core of the city protected till $20^{\text {th }}$ Century AD is taken into account as a geographical restriction. Because of the limited number of archeological excavations in the study area, only the findings of the archeological surface analysis studies done from Prehistoric Ages to Iron Age are evaluated. For later periods, rock tombs and archaeological findings around them were added. In the last section, a fragment of a wall that is one of the rare East Roman structures in the city is discussed. For this period, the existence of a city wall in Kastamonu was first presented to the litarature with archaeological material. As a result, increase of archaeological data with the Late Iron Age, it was aimed to determine the cultural stratification of the settlements reaching the $13^{\text {th }}$ century AD and the typology over the ages.
\end{abstract}

Keywords: Kastamonu, Urbanism, Paphlagonia, Sasanian, Arab, East Roman

* Arkeolog, Kastamonu Kent Müzesi, Kastamonu. paphlagonia@gmail.com, https://orcid.org/0000-0002-1573-9831 


\section{Giriş}

Kastamonu günümüzde Türkiye'nin Batı Karadeniz Bölgesi'nde yer alırken, antikçağda Paphlagonia Bölgesi'nde yer almaktaydı. Bölgenin sinırları Halys (Kızılırmak) ile Parthenos (Bartın)/Billaios (Fiyos Çayı) 1rmakları arasında kalan, kuzeyinde Pontos Eukseinos (Karadeniz), güneyinde Galatia, güneydoğusunda Kappadokia, güneybatısında Phrygia ve batısında Bithynia bölgeleri ile çevrelenmiştir (Strab. XII. 3. 9). Kastamonu il geneli yaklaşık $13.000 \mathrm{~m}^{2}$ alan kaplamaktadır. Çalışmanın odağı olan Merkez ilçe ise ilin en büyük yüzölçümüne sahiptir.

İl, genel itibarıyla dağl1k bir yapıya sahip olup, ilin ve kent merkezinin güneyinde yer alan Ilgaz Dağı'nda Büyük Hacet $(2587$ m) ve Küçük Hacet Tepeleri $(2313$ m) en yüksek zirveleri oluşturmaktadır. Küre Dağları silsilesinde yer alan Yaralıgöz (1985 m) ve Dikmen (1675 m) Ballıdă (1698 m), Bacak Dağı (1736 m) gibi önemli yükseltilere sahiptir.

Kastamonu coğrafyası genel olarak Karadeniz'e paralel uzanan iki dağ sırası ile bölünmüştür. Bu dağ sıraları Karadeniz ve İç Anadolu'ya az sayıda geçitlerle bağlanır. İki dağ arası, deniz seviyesinden ortalama yüksekliği 900-1000 m'yi bulan geniş platolarla kaplıdır. Platolar, doğu-batı yönünde şekillenirken (Gökırmak-Amnias) aynı zamanda kuzey-güney yönlü birçok küçük akarsu ile yarılmıştır. Kastamonu şehir merkezi ile Taşköprü ilçesi arasında genişleyen Gökırmak Vadisi'nin tabanı, akarsuyun sürekli taşıdığı kalın bir alüvyon dolgu ile kaplıdır (Özdoğan et al. 1997, 304).

Bölgenin su sistemlerine baktığımızda, Araç Çayı, Devrekâni Çayı ve Kızılırmak'la birleşen Gökırmak Çayı'nın ana su sistemleri olduğu görülmektedir. Kastamonu kent merkezi içinden geçen Karaçomak ve hemen kuzeyinden geçen Daday Çayı'nın parçaladığı 700-900 m yüksekliğindeki platolar üzerinde yer almaktadır.

Kastamonu tarihsel kent merkezi, Karaçomak Çayı'nın ikiye ayırdığı yamaçların eteklerine konumlanmıştır. Kastamonu'nun batı ucunu oluşturduğu Amnias Vadisi bölgenin batı - doğu doğrultulu en önemli güzergâhıdır. Bu rota, muhtemelen işlerliğini Prehistorik çağlarda kazanmış, Tunç Çağı'nda belirginleştirmiştir. Bu güzergâh, doğuda Amaseia'dan (Amasya) başlayıp, Neapolis/Neokludiopolis (Vezirköprü), Pompeiopolis (Taşköprü), Kastamonu, Daday, Eflani, Safranbolu üzerinden Amastris'e (Amasra) ve daha da batıya ulaşmaktadır (Burney 1956, 179 180; Marek 1993, 65). Bölgede Kastamonu'ya en yakın diğer bir tarihsel yol ağı da Klaudiopolis'ten (Bolu) başlayıp, Krateia (Gerede), Çerkeş, Ilgaz, Tosya'dan Halys (Kızılırmak) Havzası'na varan güneydeki Devrez Vadisi'dir (Burney 1956, 179-180) (Fig. 1).

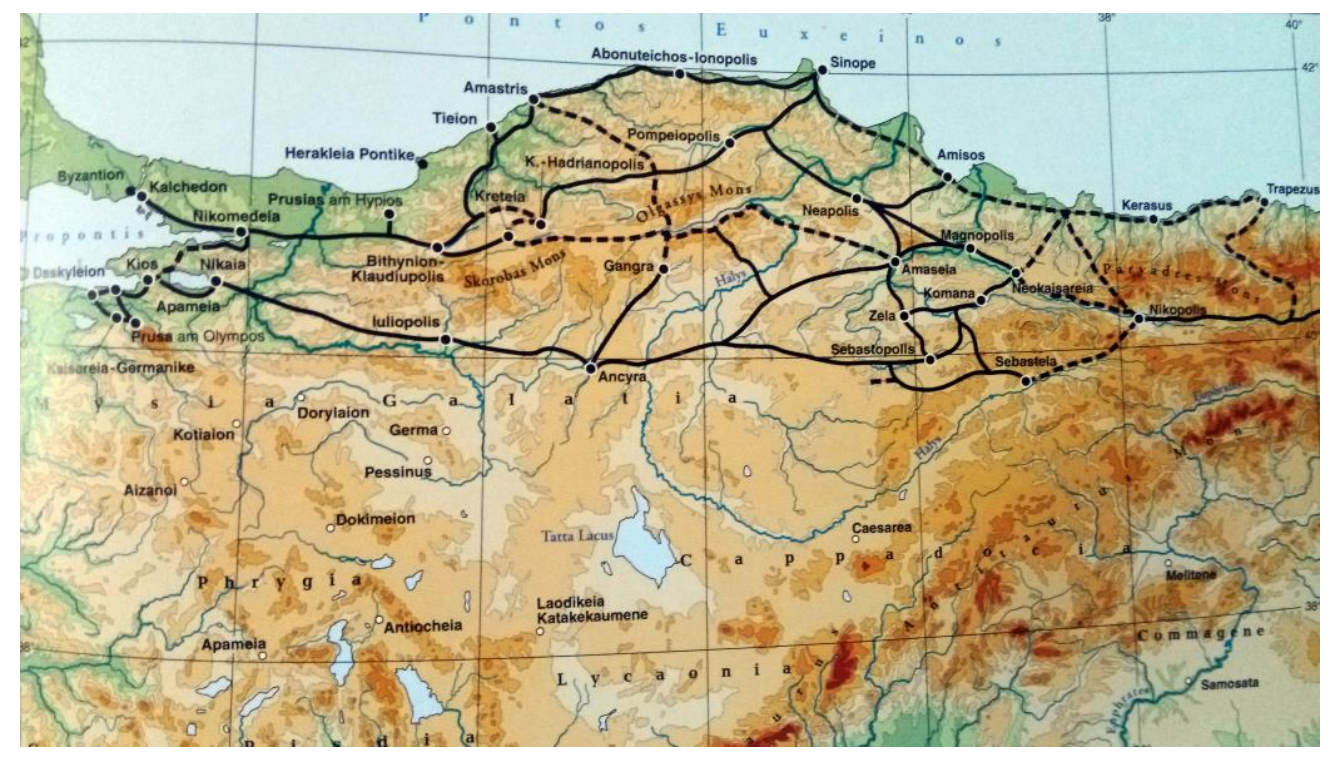

Fig. 1. Marek, 2003, Karte V-Antikçağ Bölge Yolları 
Kastamonu kent merkezi ve yakın çevresi üzerine yapılan tarih ve arkeoloji araştırmaları, 19. yüzyılın ikinci yarısından sonra başlamış, kaya mezarları ve az sayıda da epigrafik buluntular üzerine yoğunlaşılmıştır (Hirschfeld 1883, 275- 280; Hirschfeld 1885; Leonhard 1902, 1- 37; Leonhard 1915; Jacopi 1936; Jacopi 1937; Gökoğlu 1952; Akurgal 1955; Bittel \& Naumann 1965, 71- 84; von Gall 1966; Marek 1993; Marek 2003).

Kastamonu'da prehistorya alanında çalışmalar çok az olup, yine de bu çalışmalarda Kastamonu merkezini ilgilendiren bilgilere rastlanmaktadır (Şenyürek 1944, 349-352; Akok 1945, 401-407; Kökten 1948, 223-226; 1951, 201-214; Bostanc1 1952, 137-142), Burney 1956, 179-203; Donceel-Voute 1979, 196-197; Özdoğan et al. 1997, 303-330; 1998, 63-104; 1999, 219-244; 2000, 41-56).

\section{Prehistorik Çağlardan Geç MÖ I. Bine Kastamonu}

Kastamonu ili sınırlarında en erken arkeolojik veriler, Gökırmak Vadisi'nde Alt Paleolitik Çağ'a ait Acheuléen (Aşölyen) ve Micoquien (Mikokiyen) kültürlere aittir (Bostanc1 1952, 137 142). Merkez ilçeye ait en erken veriler, kentin yaklaşık 7 km kuzeydoğusundaki ve Daday Çayı Havzası'nda Gölköy mevkiinde Orta Paleolitik Levallois (Levalua) kültürüne ait çakmaktaşı aletlere rastlanmıştır (Şenyürek 1944, 349, Fig. 2).

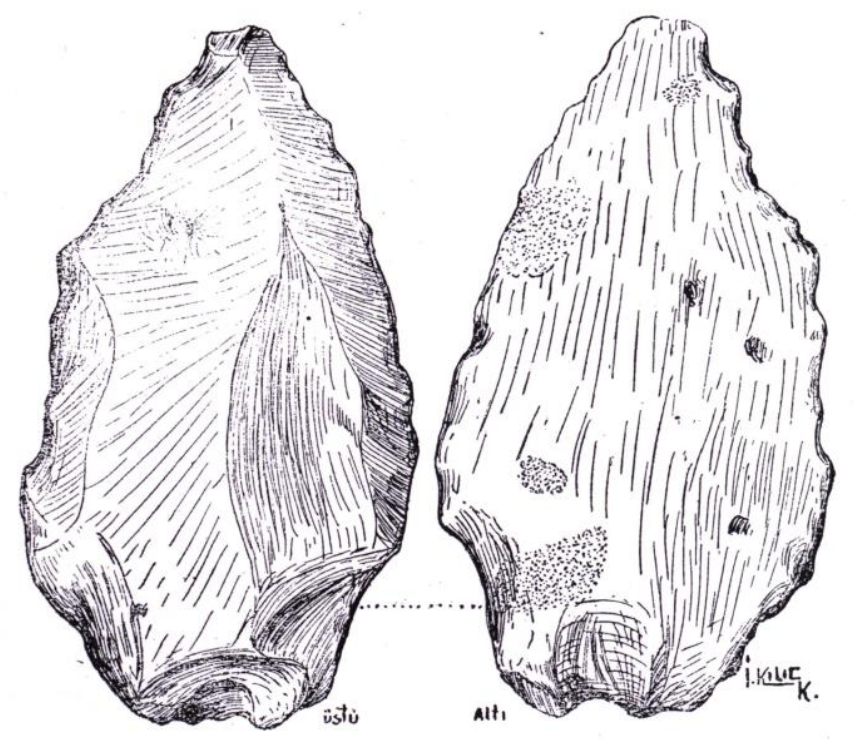

Fig. 2. Şenyürek 1944, 349, Gölköy, lövalvaziyen

Kastamonu kent merkezi ve çevresinde (yaklaşık 15 km çapta) Kalkolitik Çağ'dan İlk Tunç Çağı'na kadar, arkeolojik buluntular yalnızca yüzey araştırmalarında bulunan seramik malzemeler ile bir adet obsidyen bıçak parçasıdır. Bu buluntu merkezleri, Maltepe ve Tepecik (Burney 1956, 181), Akçakese, Hacı Muharrem, Halife, Yürekveren, Esenli, Hacı Şaban, Çakıllı gibi köylerinden gelmektedir (Özdoğan et al. 1997, 306-310; 1998, 63-104). İlk ve Orta Tunç Çağı malzemesi olarak boncuk ağızlı, kırmızı ya da kırmızı-kahverengi açkılı seramiklerle Tepecik ve Taşköprü Yolu Höyük’ten (Burney 1956, 190-192 ), ayrıca Esenli, Çakıllı, Gülef, Baltacı, Karamukmolla gibi Kastamonu'nun çevresindeki akarsularla parçalanmış platolar üzerinde yer alan köylerdeki buluntularla görülmektedir (Özdoğan et al. 1997, 306-310; 1998, 63-104; 1999, 223-225).

Kastamonu merkezinde ise özellikle kale ve eteklerinden toplanan seramikler ile obsidyen bir biçağa ait parça İlk ve Orta Tunç Çağ'a işaret etmektedir (Akok 1945, 402; Donceel-Voute 1979, 197). 
Kastamonu'nun da içinde bulunduğu Batı Karadeniz Bölgesi'nin II. binyılı tam olarak tanımlanamamıştır. Bölgedeki yüzey araştırmaları Son Tunç Çağı'na ilişkin seramik malzemeler veren yerleşimler (Gökoğlu 1952, 42; Burney 1956; Özdoğan et al. 1998, 308) belirlenmiş olsa da bu döneme ilişkin başka malzemeler ya tekil olarak ya da konteks sorunu içeriğinde döneme tarihlendirilmektedirler (Harris 1993, 251; Emre \& Çınaroğlu 1993).

Bölgede Prehistorik çağlardan Tunç Çağı'na kadar olan süreci açılayacak bir arkeolojik kazı olmamasından dolayı bölgenin erken dönemlerine ilişkin bir yerleşim tipolojisi çıkarmak henüz mümkün görünmemektedir. Ancak mevcut buluntulara ve seramiklere bakarak, bölgede yani Kastamonu kent merkezi ve yakın çevresinde zaman içerisinde yoğunlaşan bir insan etkileşimi açıkça görülmektedir. Bu durum kısa zaman önce yapılan Cide Arkeoloji Projesi ile de ortaya konmuştur. Özellikle Kastamonu'nun Cide ve Şenpazar İlçelerinde yürütülen çalışmalarda ele geçen seramik buluntular İlk Tunç Çağı ile birlikte Kuzeybatı Anadolu'nun batı bölgeleriyle arasındaki kültürel etkileşime dikkat çeker (Şerifoğlu et al. 2012, 728; Glatz 2015a, 173-174). $\mathrm{Bu}$ durum Orta Tunç ve Geç Tunç çağları için de geçerli olacaktır (Glatz 2015b, 204-205).

\section{MÖ I. Binyılda Bir Paphlagon Yerleşimi olarak Kastamonu}

Kentin MÖ I. binyıllarına ilişkin veriler, ilk olarak yazılı kaynaklardan gelmektedir. Bu kaynaklarda bölge halkı Paphlagonlar olarak tanımlanmıştır. Homeros'un İlyada'sında geçen bu halk (Hom. Il. II. 850-855), Kastamonu'yu da içine alan geniş bir bölgede ortak bir kültürü paylaşmişlardır.

Arkeolojik anlamda çok kesin olmamakla birlikte Kastamonu'da Demir Çağı'nın en erken buluntuları Merkez Gödel Köyü sınırlarındaki büyük bir tümülüsün kaçak kazı atıklarında bulunan kaliteli gri Frig seramikleri (Özdoğan et al. 1997, 309-310) ile aynı bölgedeki muhtemel çağdaş diğer üç tümülüs (Özdoğan et al. 1998, 77) olarak görülmektedir (Fig. 3).

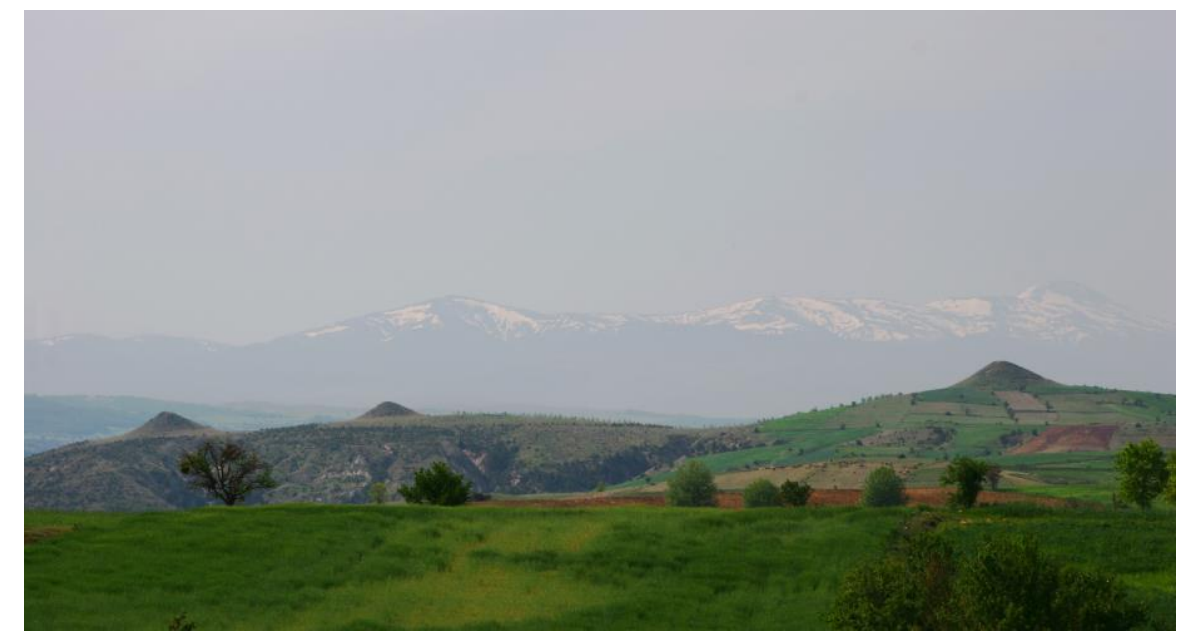

Fig. 3. Alpagut Tümülüsleri

Kastamonu'nun MÖ geç I. binyıllarına ait en önemli bilgiler kent merkezindeki kaya mezarları ve kaya fasadından gelmektedir.

Kastamonu ve içinde yer aldığı Paphlagonia Bölgesi, MÖ V. yüzyıla kadar uzanan kaya mezarı mimarisine sahiptir. Özellikle Kastamonu'nun batı ucunu oluşturduğu Amnias Vadisi'nde Paphlagon kültürüne ait çok sayıda ve görkemli kaya mezarı yer almaktadır. Bu mezarlardan başta Ev Kaya Mezarı ve Şehinşah fasadı olmak üzere birkaçı çalışmamız odağında yer almaktadir.

Şehinşah Kaya Fasadı (Ruge \& Bittel 1949, 2486 vd; Gökoğlu 1952, 134; Akurgal 1955, 
93; Bittel \& Naumann 1965, 78-79; von Gall 1966, 65-66, Sivas 1999, 5; Vassileva 2012, 244), alçak beşik çatılı $(90$ x 136 x $20 \mathrm{~cm})$ kanat biçimli tepe akroteri ile Phrygia Bölgesi'nde sıç̧a rastlanılan Kybele kaya fasadlarından biri olarak yer alır. Benzerleri ile karşılaștırıldığında fasad nişinin içinde kalan zemin konturlardaki düzensizliğin burada bir Kybele idolü olabileceğini de akla getirmektedir. Fasad, hemen yanındaki iki kaya mezarı ile aslında bir açık hava tapınım alanı olduğunu düşündürmekte ve aynı zamanda MÖ I. binyıl kültürel etkileşimi Phyrg kültürü ve Kybele inanışının bölgedeki nüfuzuna işaret etmektedir (von Gall 1966, 65; Berndt-Ersöz 2006, xx, dn. 2; Vassileva 2012, 243-254). Bu kaya fasadı üzerine yapılan araştırmalarda net bir tarihlendirme yapılmamasına karşın, tipolojik olarak Phrygia örnekleri ile karşılaştırdığımızda MÖ VI. yüzyılın ikinci yarısı gibi bir tarih vermek mümkün görünmektedir (Karasalihoğlu 2015, 73).

Geç Demir Çağı'nda Paphlagonia Bölgesi'nin bu Şehinşah Kaya Fasadı'na bakarak Frig kültürü ile etkileşimde olduğu söylenebilir. Bu durum, kendini antik kaynaklarda (Hdt. VII. 7273; Plutarch, Iside et Osiride 69), Kastamonu'dan başlayarak Amnias Vadisi boyunca uzanan kaya mezarlarında ve bölgedeki az sayıda da olsa arkeolojik materyal ile de göstermektedir (Saprykin 1991, 249-50; Laflı 2007, 53).

Kastamonu'da Frig etkisi Demir Çağı sonrasında da kendisini göstermeye devam ettiği düşünülmektedir. Buna kent merkezinde yer alan Ev Kaya Mezarı örnek teşkil etmektedir. MÖ IV. yüzyıl başlarına tarihlenen bu mezar, iki sütunlu ön cephe ve mezar odası girişinde bir hole sahip olmasıyla tapınak mezar anlayışında yapılmış; mezarın alınlığında antitetik iki sfenks arasında bir tanrıça yerleştirilmiştir (von Gall 1966, 67-73; Naumann 1983, 51). Tanrıçanın baş1 kopmuş durumda olduğundan, Phrygia Bölgesi'nde yer alan benzer örneklerde olduğu gibi başında bir polos olup olmadığı bugün bilinemese de bölgeyi, gezmiş olan Chaynkoff ve Mordtmann bu tespiti yaptıkları Leonhard tarafından aktarılır (Leonhard 1915, 260). Tanrıçanın üzerinde vücut hatlarını kapatan kalın bir elbise ve belinde de bir kemer vardır. Kolları gövdeye yapışık ve yine Phrygia örneklerinde olduğu gibi dirsekten bükülerek göğüs altında elleriyle birbirine kavuşmaktadır (Karasalihoğlu 2008, 64). Mezar alınlığında yer alan figür topluluğu, Phrygia'daki örnekleriyle örtüşürken buradaki tanrıçanın kimliğinin de ana tanrıça olduğu konusunda da görüş birliği bulunmaktadir (von Gall 1966, 68-73; Naumann 1983, 52; Işık 1999, 13; Berndt-Ersöz 2006, 154; Dökü 2008, 66-68; Saprykin 2009, 225; Vassileva 2012, 250) (Fig. 4).

$\mathrm{Bu}$ örneklerin yanında dinsel kaya mimarisi içine alabileceğimiz çok sayıda kaya mezarı da ilin kent merkezinde bulunmaktadır. Öncelikle Ev Kaya Mezarı çok açık bir şekilde kaya nekropolis'i olarak adlandırılabilecek 6 kaya mezarına daha ev sahipliği yapmaktadır. Bu nekropolis'in bulunduğu kaya kütlesi üzerinde gü-

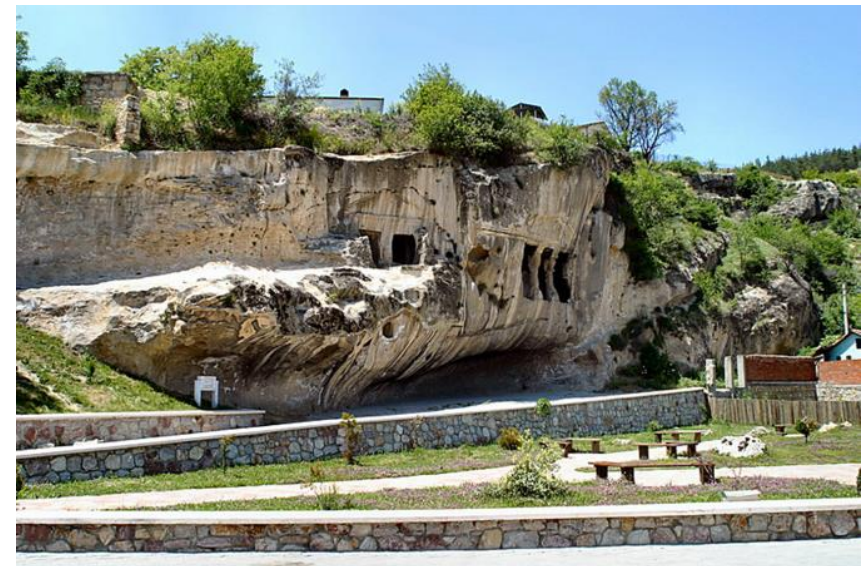

Fig. 4. Ev Kaya Mezar1 nümüzde konutlarla kapatılmıştır. Bu kayanın doğuya yöneldiği de Gümüşlüce Caddesi üzerinde deforme olmuş iki adet daha kaya mezarı vardır. Ayrıca Kastamonu Kalesi üstünde bir kaya altarı (Karasalihoğlu 2008, 67) ile MÖ IV. yüzyıla tarihlendirilen başka bir Paphlagonia tipi kaya mezarı (Dökü 2008, 177) ve Kybele Fasadı'nın bulunduğu Şehinşah kayalığında, Geç Hellenistik Dönem'e ait iki adet daha kaya mezarı bulunmaktadır (Dökü 2008, 121). 
Dinsel kaya mimarisi bulgularına bakarak Kastamonu'nun Geç Demir Çağı ve sonrasına ait verilere göre dönem ve bölge koşulları içinde Kastamonu'nun önemli bir Paphlagon yerleşimine ev sahipliği yaptığını söyleyebiliriz.

Antik kaynaklar 1şı̆̆ında Paphlagonialılar zaman zaman Korylas ve Otys gibi liderlerin etrafında toplansalar da, genelde dağınık kabileler halinde feodal beylerce yönetilmişlerdir. $\mathrm{Bu}$ anlatımlarda görülen feodal yapı, Paphlagonia Bölgesi'nde görülen kaya mezarlarının dağınıklığı ile bu kaya mezarlarının bulunduğu alanlardaki dönem yerleşimleri arasındaki bağı kurmamızı sağlamaktadır. Bu bağlamda bölgeye yayılmış, MÖ V. yüzyılın ilk çeyreğinden Hellenistik Dönem içlerine kadar görülen anıtsal cepheli kaya mezarlarının bu yerel Paphlagon bey ya da krallarına ait olduğu aynı zamanda buraların da yüksek kayalıklı akropol ve çevresindeki yerleşim olduğu düşünülebilir (Dökü 2008, 121).

Mevcut kaya mezarlarına bakarak kente ilişkin bir yerleşim tipolojisi çizmek gerekirse, bölgedeki diğer kaya mezarları bu konuda yardımcı olmaktadır. MÖ I. binyıl ortalarındaki ana yerleşim tipolojisi, bir yönetici etrafında toplanmış, çok kalabalık olmayan nüfusun, akarsuların oluşturduğu görece düzlüklere yerleştiği; bu düzlüklere hâkim yüksek kayalık alanların da yönetici akropolü olduğu söylenebilir. Bu genel tanım içinde Amnias Vadisi’nin en eski (MÖ V. yüzyıl) kaya mezarı olarak tespit edilmiş olan ve Pompeiopolis kenti yakınlarındaki Donalar Kaya Mezarı, çevresindeki ovaya hâkim bir kayalıkta yer almaktadır. Burada yapılan incelemelerde bulunan yapı temelleri, taş kesim izleri ve kayalığın çevresindeki yakınlardaki akarsuya inen basamaklı tünellerden dolayı bir kale yerleşim olarak adlandırılmıştır (Bittel \& Naumann 1965, 72 vd). Aynı şekilde Amnias Vadisi'nin doğu ucunda yer alan Salarköy Kaya Mezarı çevresinde de temel yatakları, taş kesim izleri ve basamaklı tüneller yer alırken, benzer örnekler yine Terelik Kaya Mezarı ve Asar Kaya Mezarı çevresinde de görülmektedir (Dökü 2008, 127). Bu örneklere bakıldığında Ev Kaya Mezarı'nın bulunduğu kayalık alan ile hemen yakınındaki Ortaçağ kalesinin de hem kaya mezarına ve atlarına hem de dereye inen basamaklı tüneline bakarak, Karaçomak Deresi'nin yarattığı düzlüklere hâkim bir akropol olabileceği düşünülebilir. Böylesine bir akropole sahip yerleşim, Amnias Vadisi'ne açılan toprakların en batısında bir Paphlagon yerleşimi olma ihtimalini güçlendirmektedir.

MÖ I. binyılın ikinci yarısı için önemli siyasi bir gelişme, bölgedeki Pers varlığıdır. Herodotos'a (III. 90) göre Dareios (MÖ 552-482), hâkimiyeti altındaki toprakları 20 vergi bölgesine ayırmış, Paphlagonia'yı Phrygia, Asya Thrakları, Mariandynia ve Suriye (Kappadokia) ile beraber üçüncü bölgeye sokmuş ve 360 talanta gümüş vergi vermekle yükümlü tutmuştur. $\mathrm{Bu}$ döneme ilişkin arkeolojik veri Kastamonu'nun $20 \mathrm{~km}$ kuzeybatısındaki İnceğiz Köyü Afırözü mevkiinden bulunan ve MÖ V. yüzyıla tarihlenen bir mezar steli ile gelmektedir (Donceel-Voute 1983, pl. 5, fg. 4; von Gall 1989, 143, 149-152; Durugönül 1994, 12-13, Johnson 2010, 195, 249; Dökü 2017). Bu buluntu merkezinin yakınındaki Gavurevleri yerleşimi bu noktada önemlidir. Yerleşim İlk Tunç Çağı'ndan Roma Dönemi'ne kadar devamlılık gösterirken, Orta ve Geç Demir Çağı'na ait perdahlı gri seramiği ve kaçak kazı çukurlarında da aynı çağa tarihlenen temel kalıntılarının görülmesiyle (Özdoğan et al. 1999, 222-223; Johnson 2010, 345) belki de kent merkezindeki kaya mezarlarının bulunduğu Paphlagon merkezli yerleşime koşut bir Pers yöneticisinin de yerleşik olduğu başka bir yerleşimi gösteriyor olabilir.

\section{Hellenistik ve Roma Dönemi Kastamonusu var mıydı?}

Bölgenin henüz pek de tanımlanamamış bir başka dönemi ise Hellenistik Dönem ve sonrasıdır. Paphlagonia Bölgesi Büyük İskender'in seferi sonrasında önce I. Antigonos Monophtlamos'un egemenliğine girmiş (Diod. XVI. 90. 2; XX. 111.4) daha sonra ise Ipsos Savaş1 (MÖ 301) ile Lysimakhos hakimiyetinde kalmıştır (Arslan 2007, 51). Aynı tarihlerde de Mithradates I Ktistes Kimiata'da Mithradates Hanedanlığı'nı kurmuş ve kısa sürede Paphlagonia'nın iç bölgelerini 
ele geçirmiştir (Arslan 2007, 51-52).

Bölge bu dönemden sonra zaman zaman bağımsız zaman zaman da bölge krallıkları arasında el değiştirmiş; Pompeius Magnus'un MÖ 66'da Mithradates VI Eupator'u yenilgiye uğratmasıyla Roma hakimiyetine girmiştir (Strab. XII 1. 3; Marek 1993, 39; Arslan 2007, 446 vdd.).

Geç Hellenistik Dönem için günümüz Kastamonu sınırlarında kaldığı düşünülen iki antik kente dair tek yazılı kaynağımız Strabon'dur. Bu kentler Olgassys (Ilgaz) Dağı'nın kuzeyindeki Blaene ve Dominitis'tir (Strab. XII. 3. 40).

Dominitis'in, Strabon'un (XII. 3. 40) aktarımlarına göre I. Mithradates Savaşları'nda bu kent yakınlarında yapılan ve Pontus Krallığı'nın Bithynia ordularına karşı kazandığı çarpışmadan sonra Pompeiopolis kentinin kurulduğu yerdir.

Blaene kenti ise yukarıda anılan savaşta Bithynia kralı Nikomedes IV Philopator'un (MÖ 94-74) izlediği yolun üzerinde olduğu kenttir (Arslan 2007, 130-132). Antikçağda Paphlagonia üzerinden Pontus'a ulaşan yolun Blaene ve Dominitis üzerinden geçen güzergâhlardan biri olması (Marek 1993, 65), Blaene'nin batıdan doğuya ilerleyişte Dominitis'ten önce gelmesi ve Strabon'un İç Paphlagonia'da ve Amnias Vadisi'nde sadece bu iki yerleşimi sayması buranın Kastamonu ya da çok yakınında bir yer olabileceğini düşündürmektedir?

Merkez ilçe çevresinde yapılan yüzey araştırmalarında Halife, Kayalı, Höyüktepe, Kurusaray İnceboğaz, Çakıllı, Gülef ve Mollaahmet köylerinde Hellenistik ve Roma Dönemi seramik parçalarına rastlanmıştır (Özdoğan et al. 1997, 307-309; 1999, 224-225). Kent merkezine daha yakından baktığımızda Geç Demir Çağı ile başlayan dinsel kaya mimarisine bakarak bu kaya mezarlarının Hellenistik ve Erken Roma Dönemi'ne kadar da gitmesi kent sınırları içinde zayıf da olsa bir yerleşimin izlerini göstermektedir. Ayrıca, Kastamonu'da Yılanlı Cami'de (MS 1282) kullanılmış olan grilandlı lahit yan yüzeyi ve yumurta-ok silmeli lento ile İsmail Bey Camisi tabanında bulunan akantus yapraklı ve yumurta-ok silmeli entablatür parçası döneme ilişkin devşirme malzeme olarak görülebilecek tekil antik çağ bulguları da vardır (Karasalihoğlu 2012, 448-451). Ayrıca L. Woolley'in günümüzde Bahçeşehir Koleji olan o dönem ki Rum Okulu'nun altındaki bir yükseltiyi tümülüs olarak tanımlaması da bölgede yerleşime işaret edecek bir bilgi olabilir (Woolley 1921, 32, 41). Öte yandan Cide Arkeoloji Projesi'nde ilin kıyı kesimlerinde de az sayıda arkeolojik materyalle temsil edilen Hellenistik Dönem'in çalışma kapsamında kalan iç kesimde görülmediği ve dönem karakterinin kıyı ile sınırlı kaldığı belirtilmiştir (Şerifoğlu- Bakan 2015, 254).

Özellikle Roma Dönemi içinde kent merkeziyle bağlantı kurulabilecek iki nokta Kastamonu'nun $10 \mathrm{~km}$ uzağında yer almaktadır. Bunlardan ilki kuzeyde Kara Çay boyunca uzanan vadi yatağındaki Duruçay Köyü ve çevresidir. Buradan ele geçen iki yazıt (Marek 1993, 153, Kat No:65; Kat No: 68) ile köyün Candaroğlu Beyliği'ne tarihlenen Halil Bey Cami inşaatında kullanılmış olan yarım yivli sütunlar, entablatür parçaları, konsollar ve kompozit başlıklar Roma (Dönemi'ne işaret eden önemli bir yerleşim ve mimari varlı̆̆ 1 göstermektedir. Keza köyde daha önceden tespit edilmiş 3 tümülüs ve hemen yakınındaki Halifekuyucağı ve Kırcalar köyündeki tümülüsler de aynı döneme ait olmalıdır (Gökoğlu 1952, 49). (Fig. 5)

İkinci önemli nokta ise Kastamonu'nun hemen güneyindeki ovalık alan ile özellikle de Kastamonu merkezinin yayılımı boyunca paralel olarak ilerleyen güney-kuzey doğrultulu Karasu Deresi ile İydir Deresi (Her iki dere de Amnias-Gökırmak'a bağlanmakta) arasında kalan platolar ve dereler boyunca oluşan vadilerdeki çağdaş köylerin antik yerleşimlerin üzerine oturmasidir. 
Kastamonu'yu kuşatan kuzeyde Daday Çayı ve Kara Çay'ın oluşturduğu vadiler ile güneyde Elmalı ve Karaçomak Çayı'nın oluşturduğu ovalık alanlarda erken dönemlerden itibaren yerleşim görmeye başladığı yapılan yüzey araştırmaları ile tespit edilmiştir (Burney 1956, 180192; Özdoğan et al. 1998). Kastamonu'nun doğusunda bu iki su sistemi ile parçalanmış arazi ise özellikle klasik çağlar için yoğun arkeolojik veriye sahiptir.

Karasu Deresi boyunca güneyden kuzeye doğru Seremettin (arslan heykeli ve phallos), Akdoğan, Etyemez ve Sırasöğütler (yoğun kaya mezarı, tümülüs, seramik), Kayalı (kaya mezarları ve nekropolis); İydir Deresi boyunca, Damlaçay, Darıbükü, Kızılkese (yap1 kalıntıları, seramik), Demirci (seramik ve cüruf atıkları), Karaş ve Alpagut (toplu sikke, yazıt, ana kayaya oyulmuş mezarlardan oluşan geniş bir nekropolis, üçü tescilli 10 adet tümülüs, pişmiş toprak figürünler, altar ve ostetek) köyleri ve çevresinde vadinin yoğun olarak iskân edildiği görülmektedir.

$\mathrm{Bu}$ noktada belki de Geç Demir Çağı sonrasında Kastamonu kent merkezinde yer alan yerleşim ağırlığı Geç Hellenistik Dönem ile birlikte yaklaşı $10 \mathrm{~km}$ doğudaki vadi yatağına kaymış olabilir. Bunun nedeni olarak da özellikle Mithradates-Roma Savaşları'nın bölgeyi tahrip etmiş olması, özellikle Birinci Mithradates-

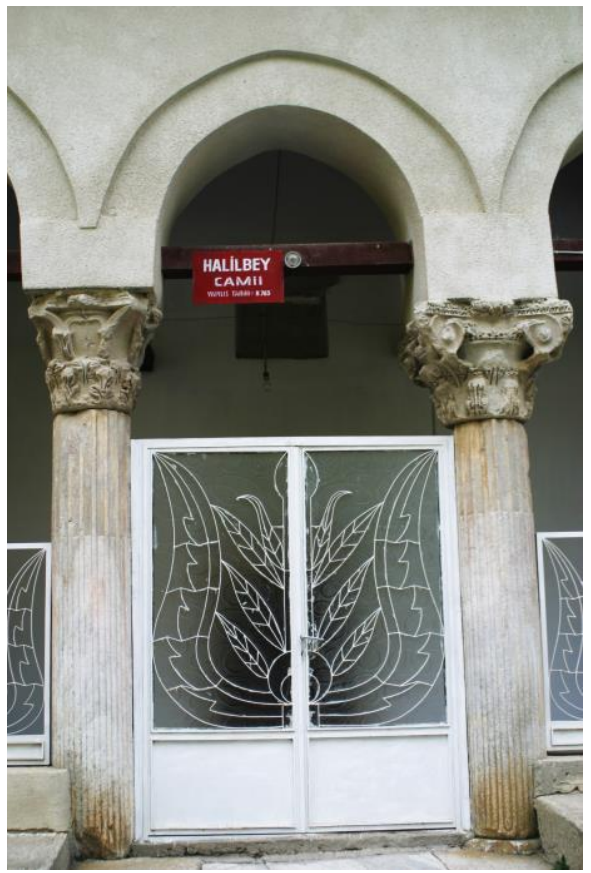

Fig. 5. Duruçay Köyü Halil Bey Cami Roma Savaşı'nın bazı safhalarının Amnias Vadisi'nde gerçekleşmiş olması etkilemiş olabilir (Arslan 2007, 127). Karaçomak Vadisi üzerine kurulmuş olan Kastamonu'nun mevcut veriler ışığında doğu-batı bağlantısını sağlayan daha eski ve bilinen bir güzergâh olmasından dolayı belki de bölge iskâncıları daha talihi bir güzergâha yerleşerek kendilerini güvene almak istemiş olabilirler.

$\mathrm{Bu}$ tarihten sonra Kastamonu'nun da içinde olduğu Paphlagonia Bölgesi Roma İmparatorluğu'nun yapmış olduğu çeşitli düzenlemelere bağlı olarak Gangra ve Pompeiopolis'in bölge metropolisi olmasından dolayı tarihsel akış ve özellikle de bölgede kentleşme bu yerleşimler üzerinden izlenebilmektedir.

Pompeius Magnus MÖ 66'da Mithradates VI Eupator'u yenilgiye uğratarak kesin zafer elde etmesinden sonra bölgede bazı idari düzenlemeler yapmıştır. MÖ 65/64'te Pompeius, Mithradates'in krallığını bölmüs ve Pontus Eyaleti'ni 11 kentin territoriumlarını kapsayacak şekilde düzenlemiştir. Bunlar; Amastris, Sinope, Amisos, Pompeiopolis, Neapolis/Phazemon, Diospolis/Kabeira, Magnopolis/Eupatoria, Megalopolis, Zela, Herakleia ve Tieon'tur (Strab. XII. 1. 3; Marek 1993, 39; Arslan 2007, 446 vdd.; 484 vdd.). MÖ 63'de Pompeius lex Pompeia ile Pontos Krallığı'nın batısını Bithynia'ya ekleyerek Pontus-Bithynia çifte eyaletini kurmuştur (Strab. XII. 3. 1). Paphlagonia Bölgesi'nden bazı kentler de bu eyalete dâhil edilmiştir (Marek 1993, 36-39; Arslan 2007, 487-490). Bu düzenlemede Paphlagonia'daki Pompeiopolis (Taşköprü) ve Neapolis (Merzifon) kentlerinin toprakları Bithynia-Pontus eyaletine bağlı değildi (Strab. XII. 3. 38; 41).

\section{Roma Sonrası Akınlar ve Bölge Yerleşim Modelinin Değişmesi}

Kastamonu'nun da içinde bulunduğu toprakların Roma idaresine geçmesinden sonra uzun yıllar süren savaşsızlık (pax Romana) ortamı oluşmuştur. Ama bu durum öncelikle MS III. yüzyıl, asıl olarak da MS VII. yüzyılın başlarından itibaren bozulmuş, bölge Got, Sasani ve Arap akınlarıyla 
tanışmış ve öncelikle idari daha sonradan da biçimsel olarak değişimler geçirmiştir (Ahrweiler 1962, 1-32; Brüggemann 2012, 42-52).

Bölgenin kitlesel anlamda ilk tahribatının Gotlarca yapıldığı söylenebilir. Gotların Asia Minor'daki ilk saldırıları MS 257/8-262 y1llarında olur. Daha sonra ise 267 y1lında Gotlar, Bithynia, Galatia ve Kappadokia'yı yağmalarlar. Bu akınların Paphlagonia'ya kadar ulaştı̆̆ını göstermesi açısından Kastamonu'nun hemen güney batısında yer alan Karzene Köyü'nde (Belke 1996, 227) bulunan bir mezar steli örnek teşkil eder. Stelde, işgalcilerin Pontus'tan, yani Karadeniz'den gelip Hadrianopolis'e kadar genç kadınlara tecavüz ettiği yazmaktadır (Kaygusuz 1984, 61-63). Bu noktada Got saldırıları karşısında Anadolu'nun diğer yerleri kadar olmasa da (Brüggemann 2012, 46) bölgenin bu akınlardan etkilendiği düşünülebilir. Keza bölgedeki Antikçağ' 1 en önemli kültlerinden biri olan ve Ionopolis kentinde faaliyet gösteren Glykon Kültüne ilişkin arkeolojik buluntuların MS 251-253 yıllarından itibaren bıçak gibi kesilmesi, akınların Karadeniz'den iç kesimlere ulaşması adına fikir verebilir. Glykon Kültüne ilişkin bilinen en geç arkeolojik veri İmparator Trebonianus Gallus (MS 251-253) dönemine ait bir Ionopolis sikkesidir (Karasalihoğlu 2017, 186). İmparator Trebonianus Gallus'un yönetiminin hemen öncesi ve sonrasında Roma İmparatorluğu'nun Karadeniz kıyıları ile Dacia ve Thrakia bölgeleri Gotlar'ın yıkıcı saldırılarına maruz kalmıştı. MS 255-257 tarihleri arasında Gotlar, Borani adlı bir grupla birlikte Doğu Karadeniz'e saldırılar düzenlemiş ve Pontus Bölgesi'nin büyük bir kısmı ile Trapezus kentini ele geçirmişlerdi. Saldırıların devamında ise Karadeniz'in güney batı kıyılarında Khalkedon, Nicaea, Nikomedia, Prusia gibi kentler yağmalanmıştır (Zos. HN. I. 18-19). Bu noktada Karadeniz kıyı şeridine hem doğudan hem de batıdan yapılan saldırılarda Ionopolis'in dolayısıyla iç Paphlagonia'nın da olumsuz yönde etkilenmiş olması muhtemeldir.

Got akınlarının ardından, MÖ VII. yüzyıl başı itibarıyla bölge bu kez de Sasani akınları ile karşılaşır. İran Hükümdarı Hüsrev Perviz, MS 609 yılında Anadolu'ya girerek Parthia ve Kappadokia ile birlikte Paphlagonia'yı da talan etmiş, daha sonra Doğu Roma imparatoru Heraklius bölgede güvenliği sağlamıştır (Honigman 1970, 5,19, 44). Keza yine Sasani orduları MS 620'de Ankyra yolu ile kuzeye yönelmişler ve MS 621-23 y1llarına kadar Pontus'ta kalmışlardır. Ancak genel olarak kabul edilen görüşlere göre Paphlagonia'nın Sasani akınları sırasinda pek de zarar görmediği üzerinedir (Brüggemann 2012, 47-48).

MÖ VII. yüzyıl ortalarında Anadolu'ya Arap akınları başlar. Ancak bu akınlar bölgeye VIII. yüzyıl başlarında ancak ulaşır. Arap akınlarının rotaları Tyana, Caeseria, Chorsianon, Ankyra, Gangra ve buradan da Paphlagonia içinden Sinope ya da Herakleia Pontike'ye kadar uzanmaktaydı. Doğudan gelen rota ise Sebasteia, Neokaiseria, Amaseia, Amisos hattı da Paphlagonia'y1 tehdit etmiştir (Ahrweiler 1962, 10).

MS 712 yılında Gangra ele geçirilirken 715 yılında Muhammed bin Mervan idaresindeki Arap kuvvetlerinin Anadolu'ya girerek Karadeniz sahilini kapsayan bölgeyle birlikte Paphlagonia'y1 da geçici olarak ele geçirir (Yinanç 1944, 33; Brüggemann 2012, 48; Uçar 2012, 117). Muaviye (Süleyman b. Hişam) döneminde (MS 731-788) Araplar yeniden Paphlagonia'ya saldırmış özellikle Gangra'ya büyük zarar vermiş, MS 741-742 yıllarındaki son saldırıda ise bölge ciddi zarar görmüştür. Keza bu dönemde Constantinapolis'teki iç siyasal kargaşadan dolayı Doğu Roma Devleti ise bölgeye neredeyse hiç uzanamamıştır (Uçar 2012, 134). Araplar en son MS 863 y1lında bölgenin doğusunda Samsun-Sinop hattında görülmüşlerdir (Brüggemann 2012, 48-49).

Bölgedeki ana idari ve fiziksel değişim görüldüğü üzere özellikle Sasani ve Arap akınların yoğunlaşmasıyla birlikte MS VII. yüzyıl ile birlikte başlayacaktır. Her ne kadar Got saldırıları bir kenara bırakılırsa bu yüzyıldan sonra başlayıp sürekli devam edecek olan istila, akın ve 
yağma hareketleri sonucunda, büyük ihtimalle bölgedeki birkaç merkez dişında ovalık alanlara dağılmış olan yerleşimler bu yüzyıldan sonra tahkimatlı yerleşimler olarak birleşmeye, Pompeiopolis gibi merkezi yerleşimler de kastrona dönüşmeye başlayacaktır. Bu duruma uygun düşen bir örnek Pompeiopolis'in 7,5 km kuzeydoğusundaki Kızlar Kalesi verilebilir. Kale, Pompeiopolis kentine ait mimari parçalarının yeniden kullanılmasıyla yapılmış ve geç VI. yüzyıl erken VII. yüzyıla tarihlendirilmiştir (Crow 1996, 22-24). Keza benzer durum imparatorluğun başka yerlerinde de bu yüzyıllara ilişkin büyük savunma inşalarında da görülebilir (Crow 1996, 24). Benzer bir gözlem Kastamonu'nun kıyı kesimi için de yapılmaktadır. Kıyı şeridindeki yerleşimlerin MS VII. yüzyıla doğru küçülüp, yerel ekonomiler olarak içe kapanmış ve kale çevresindeki kırsal yerleşimler olarak hayatını sürdürürmüş, bu durum MS VIII. yüzyıldan sonra değişmiş ve MS 11. ve 12. yüzyıllarda Komnenoslar Hanedanlığı sırasında da tahkimatlı yapılar güçlendirilip geliştirilmişlerdir (Casis 2015, 358-359).

Ahrweiler, Anadolu üzerine Arapların akınları konusunda tartışmasında Gangra gibi tahkimatlı şehirlerin öneminin arttığını söyler. Ahrweiler'in ayrıca öne sürdügü, akınların aynı zamanda platodan uzak şehirlerin büyümesini geliştirdiği ve bu yüzden de şehirlerin siperleştiği, örnek olarak da Kastamonu ve Amastris şehirlerini verir. Özellikle Pontus Bölgesi’nde Kastamonu'nun bulunduğu durum Herakleia, Amisos, Sinope, Trabzon gibi kentlerde de olurken, Batı Anadolu'da Adremytton, Smyrna, Ephesos, Miletos gibi kentlerde de görülmektedir. $\mathrm{Bu}$ noktada Ahrweiler, Kastamonu'nun IX. yüzyıl veya hemen öncesinde kentsel bir yerleşime de kavuşmuş olabileceğini de savunur (Ahrweiler, 1962, 28-29). Bu kentler Arap akınları sırasında güçlendirilmiş şehirler durumuna gelirken, muhtemel Kastamonu küçük bir yerleşimden bir kastron'a yani kaleler ile güçlendirilmiş bir şehre dönüşerek çevre yerleşimlerin merkezi olmaya başlamıştır. Taşköprü Kız Kalesi'nden de izleneceği gibi bölgenin uzun yıllardır merkezi olan Pompeiopolis gibi kentler ise VIII-IX. yüzyıldan sonra çöküşe geçip sadece piskopos listelerinde var olan küçük yerleşimlere dönüştüler ve onların işlevini Kastamon gibi yeni kentler devir ald1 (Crow 1996, 34-35; Bryer \& Winfield 1985, 12). Bu noktada Kastamonu örneğine bakarak, mevcut kalenin ilk nüveleri Komnenoslar öncesi atılarak, bir ara dönem olarak Paphlagonia MÖ I. yüzyıldan önceki dinastik kale kentli yerleşim şekline yeniden bürünmüştür (Crow 1996, 35).

Bölgede bu akınlardan kaynaklı tahkimatlı yerleşimlerin oluşması MS VIII. yüzyıl ile başladığı düşünülmekte ise de bu durumun konumuz olan Kastamonu merkezi için daha geç olduğu anlaşılır. Constantinus Porphyrogenitus (MS 913-959) yazmış olduğu De Thematibus et de Admintranto Imperio adlı çalışmada, Paphlagonia Themasını açıklarken bölge kentleri olarak başkent Gangram, daha sonra Amastram, Soram, Dadybram, Ionopolim ve Pompeiopolim kentlerini sayar (Const. Prophy. I. 29). Bu durumda X. yüzyılın ikinci yarısında hala Kastamonu'yu bir isim altında ve bir kent ya da kastron olarak görmek henüz mümkün değildir.

\section{Kastamonu'nun Kent Haline Gelmesi}

Bugün bir kent olarak gördüğümüz Kastamonu'nun temellerinde bölgedeki VII. yüzyıldan başlayan yerleşim tipolojisi değişimleri ve hemen akabinde de Komnenos Ailesi varlığ gelmektedir.

Komnenos Ailesinin bilinen ilk üyesi Doğu'nun strategos autokrator'u olan Patrikios Manuel Erotikos Komnenos'tur (MS 955/60-1020). O, 11. yüzyıl başlarında Kastamon çevresinden edindiği geniş mülklerle kenti, ailenin kalesi haline getirecektir. Komnenos ismi Thrakia Hadrianopolis yakınlarındaki Komne (Plovdiv-Filibe yakınlarında) Köyü'nden gelmektedir. Thrakia kökenli olmalarına karşın Paphlagonia'daki mevcudiyetlerinden dolayı doğulu bir soylu aile olarak kabul edilmiştir (Kazhdan 1991, 1143-1144; Varzos 1984, Vol A, 25-26). Kastamon, tarihte ilk defa I. Isaac Komnenos'un (MS 1007-1060) imparator ilan edildiği (önce 8 Haziran 
1057) 1 Eylül 1057 yılında ortaya çıkmıştır (Foss 1991, 1110).

Manuel Erotikos Komnenos ilk defa isyancı General Bardas Skleros'un imparator II. Basil'e (MS 976-1025) karşı başlattığı isyanında Nicaea'nın savunulmasında ortaya çıkar. Komnenos burada başarılı bir savunma gösterse de sonunda teslim olmayı kabul etmiş ancak kent sakinlerinin güvenli bir şekilde Constantinopolis'e götürülmesini sağlamıştır. Manuel Erotikos Komnenos, ikinci olarak da MS 989 yllında isyanc1 Skleros'un teslim olmaya ikna edilmesinde İmparator Basil tarafından gönderilen elçi olarak kayıtlara geçer. Kayıtlarda kendisi için patrikios, antypathos ve vestes unvanları kullanıldığı görülür (Bryennios, I, 1; Runciman 1951a, 54-55).

Kastamon'un isminin ilk duyulduğu (Burada Doğu Roma kaynakları direkt olarak Kastamon olarak değil Doğu ve Paphlagonia olarak anılmaktadır) ve bir kastron olarak karşımıza çıktığı dönemin sahibi Isaac Komnenos, askerî bir aileden gelen bir aristokrat olarak imparator olmuştur. Paphlagonia'daki toprakları İmparator II. Basil tarafindan muhtemelen Nicaea'ya savunmasından sonra babası Manuel Komnenos'a verilmiş ve o da oraya "Kastra Komnenos" olarak bilinen büyük kaleyi inşa etmiş ve burası da bugün hala "Kastamonu" diye bilinmektedir (Runciman 1951a, 54-55). Kastamonu kelimesi ilk olarak MS 12. yüzyıla ait

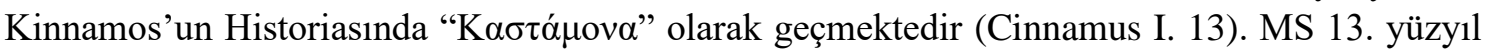

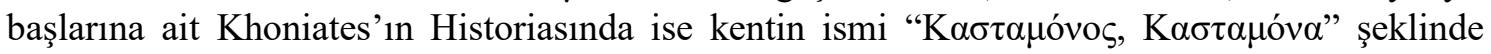
görülür (Khoniatae I, 28).

Komnenos Ailesi'nin güç merkezi ve zenginliği Doğu Roma kaynaklarına göre Paphlagonia'daki Dokeianoi ve Doukai aileleri dâhil diğer güçlü aileler ile özellikle Paphlagonia'daki evliliklerinden gelmektedir. Ayrıca bu dönemde kale ile birlikte Kastamon, Komnenosların aile mülkiyetindedir (Bryer \& Winfield 1985, 7; Crow 1996, 16; Laiou 2009, 59). I. Isaac Komnenos 8 Haziran 1057'de (Psellos, Book 7, 5; Attaleiates, 2, 2) Kastamonu merkezine çok yakın bir noktada imparator ilan edilmiştir ve gitmeden önce ailesini Doğu Paphlagonia'daki muhtemelen başka bir Komnene kalesi veya müttefik bir ailenin kalesi olan Pimolissa kalesinde güvenceye almıştır. Kastamonu (bölge) burada Isaac Komnenos'un evi olarak tanımlanmıştır. $\mathrm{Bu}$ bilgilere bakarak Isaac ve Manuel Komnenos'a ait bilgiler Kastamonu'ya ilişkin en erken bilgileri de bize göstermektedir (Belke 1996, 232; Crow 1996, 16).

1057 y1lında Isaac Komnenos'un imparator ilan edilmesiyle imparatorluk ailesi Kastamon'dan çıkmış bu tarihten itibaren kent, Türkler ve Doğu Romalılar arasında el değiştirmeye başlamıştır. Keza kentin ya da kastronun bir nevi terk edilmiş olduğu izlenimi Aleksios Komnenos Russel'ı tutuklamak için çıktığı seferden başkente dönerken (MS 1075), dedesinin kentine uğradığı bilgisiyle Anna Komnena'dan gelir (Anna Komnena, Aleksiad, I.II.3; Bryennos, II, 26). Burada Aleksios'un konakladığı dede evi olarak, Kastamon kastedilmektedir (Aleksiad, 22, dip not. 4, çevirmenin dipnotu; Belke 1996, 232; Crow 1996, 16). Aleksios Komnenos aslında başkente ulaşan ana yol ağı olan Devrez Vadisini kullanırken, bu yol üzerindeki akrabaları olan Theodora Dokeinaos'a uğramış ve buradan kuzeye yol alarak Kastamon'a ulaşmıştır. Bu olay Anna Komnena ile çağdaş Nikephoros Bryennios tarafından da aktarılmış, Aleksios Komnenos Kastamonu'daki kaleyi boş ve ıssız bulmuş, hatta buradan ayrılırken Türkmenlerin pususundan zor kurtulmuş daha sonra Heraklia Pontika'ya ulaşarak buradan deniz yoluyla Konstantinopolis'e ulaşmıştır (Crow 1996, 12-13).

1071 Malazgirt Savaşı'ndan sonra Türk akınları hızlıca Anadolu içlerine yayılmaya başlayacak (Dukas 1956, 5, 92, 253) ve Kastamon, 1084 yılında Danişmendli Karatigin Bey tarafından ilk defa ele geçirilecektir (Yücel 1991, 128). I. Haçlı Seferleri sirasında Kont Raymond özellikle İmparatorluğun başında bulunan Komnenos Ailesini hoşnut etmek üzere Gangra üzerinden Kastamon'u ele geçirip Karadeniz kıyısına ulaşmak istemiştir. 1101 Temmuz 
ayında ordusunu Kastamon'a yönelten Kont Raymond, hem Türklerin aldıkları önlemler ve baskınları hem de hava şartları nedeniyle yıpranan ordusuyla kent önüne kadar gelebildiyse de kenti ele geçiremeden doğuya devam etmek zorunda kalmıştır (Runciman 1951b, 22-23). Bu tarihten sonra kent önce yeniden Doğu Roma, sonrada 1124 yılında Danişmendli Emir Gazi tarafindan tekrar Türklerin eline geçer. 1130 yılında, İmparator Ioannes Komnenos, Kastamon'u ellerinde bulunduran Danişmend oğullarına karşı taarruza geçer ve surlara karşı koçlar ve hücum merdiveni kullanarak kaleyi ele geçirir. Bu kuşatma sırasına kenti elinde tutan Danişmendli vali kaçmış ve İmparator Ioannes Komnenos yanında birçok Türk esir ile Konstantinopolis'e dönmüştür (Khoniates, 5.26; Kinnamos 1.13; Chalandon 1912, 82-91; Runciman 1951b, 210) İmparator bu zaferin anısına Konstantinopolis'de 1133 yılında görkemli bir tören düzenlemiştir (Khoniates 5.26).

1134 yılı Eylül ayında Persamen Taismanios (Danişmend oğlu Emir Gazi) Kappadokia Hâkimi olarak Kastamonu'yu yeniden ele geçirmiş (1132 ya da 1133 yılında kuşatılmış ve kent açlıktan direnci kırılınca ele geçmiştir) ve kentteki Doğu Roma garnizonu kılıçtan geçirilmiştir. Ioannes yeniden düzenlediği sefer ile şehrin önlerine geldiğinde Emir Gazi ölmüştür. Şehir Emir Gazi'nin oğlu Mukhumet (Muhammed) idaresi altındadır. Ioannes yaptığı kuşatma ve saldırı ile Kastamonu'yu ardından da Gangra'yı tekrar ele geçirmiştir (Khoniates 1.28; Kinnamos 1.14-15).

1143 yılında Selçuklu Sultanı Mesud bölgeyi kısa bir süre egemenliği altına almış ancak bölge sonra yine Doğu Roma hâkimiyetine girmiştir (Turan 1968, 221). 1204 yllındaki Latin işgali sonrasında Komnenos Ailesi'nden Aleksios I ve kardeşi David bölgeyi kısa süre yönetmiş (Kursanskis 1977, 244) ama 1211-1212 yılında Kayı Boyu'ndan Çoban Ailesi eliyle kent kati olarak Türk egemenliğine girmiştir (Fig. 6).

\section{Kastamon (Kastamonu - Kastra Komnen) Kalesi ve Sehir Surları}

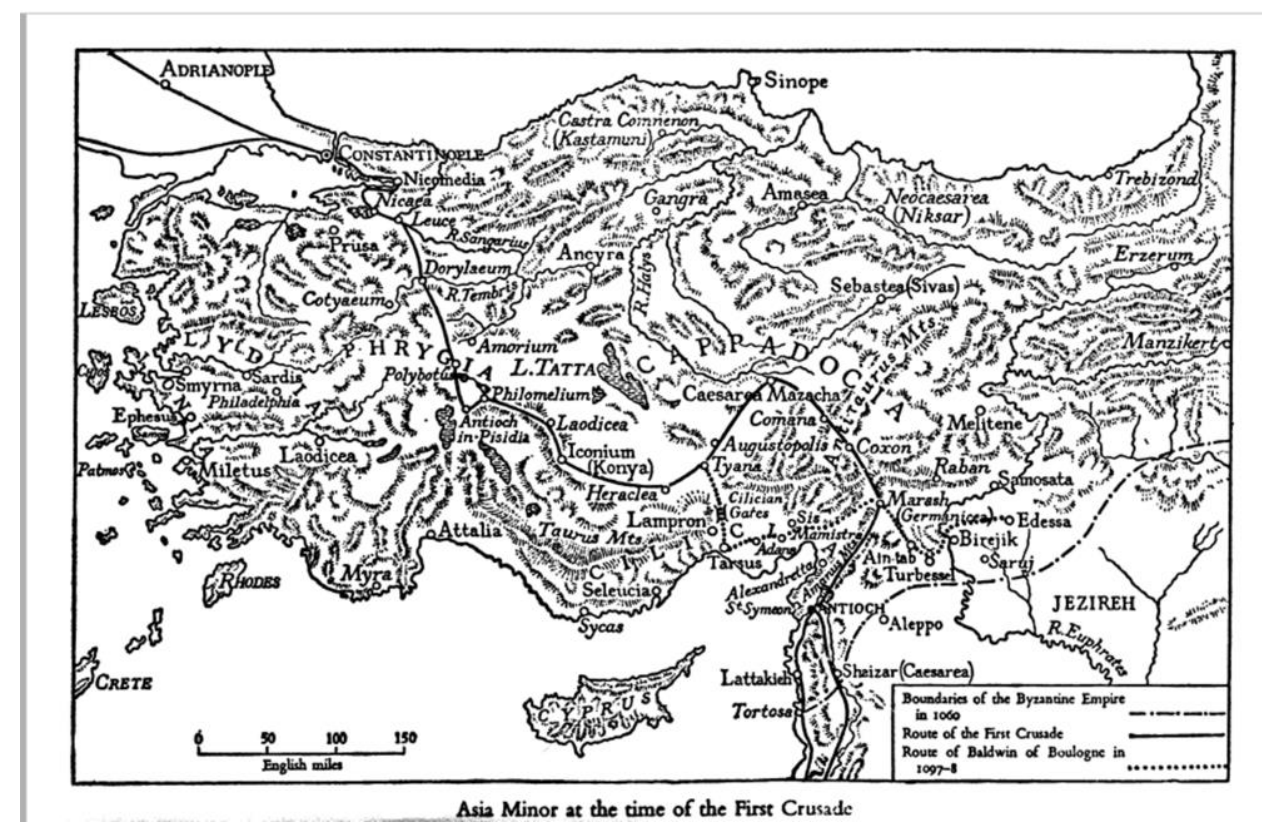

Fig. 6. Runcimann-176-first crusaders

Kale, Kastamonu kent merkezindeki Doğu Roma Dönemi'ne ait yegane arkeolojik bulgudur. Kale, doğuda Karaçomak, batıda Kerpiçlik ve güneyde de Vakıf Derelerinin (Kerpiçlik ve Vakıf Dereleri günümüzde doldurularak yol haline getirilmiştir) oluşturduğu boğazda yükselir. Kale Kastamonu'nun güneybatı çeyreğinde 112 m yüksekliğinde dik yamaçlı kaya çıkıntıları üzerin- 
dedir. Kuzeybatısında alçak bir geçit ile biten yüksekçe zeminle bağıntılıdır ve sadece burası ve bunun kuzeyinde bulunan ve uzanan kısmı sayesinde kaleye ulaşmak mümkündür. Kalan diğer bölümlerde ise vadi tabanına düşen sarp kayalıklar vardır (Fig. 7-8).

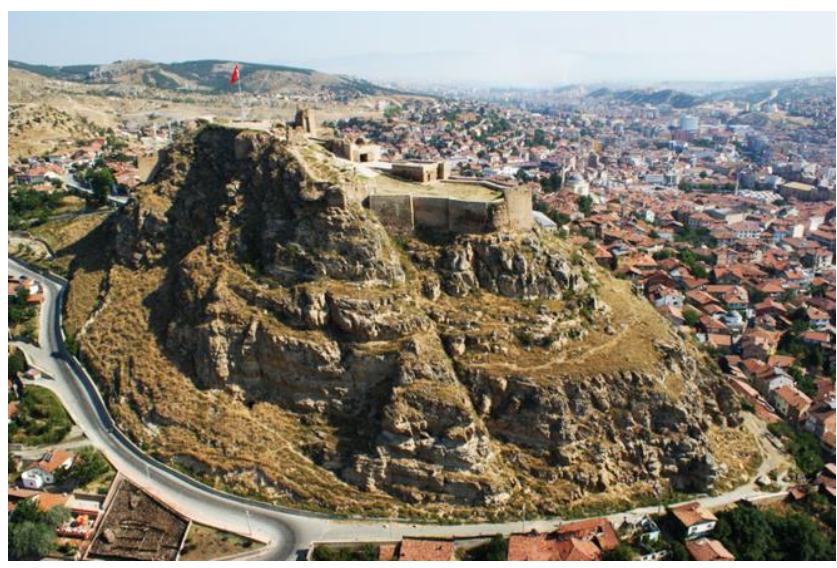

Fig. 7. Kastamonu Kalesi

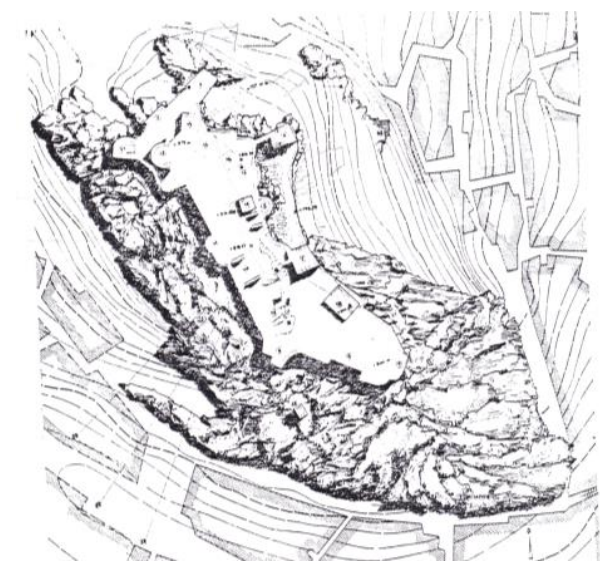

Fig. 8. Akok, 1945, L.75

Kalenin üzerinde yer aldığı kısmen piramidal kaya kütlesinin dere yatağıyla birleştiği zeminde hem de kaya kütlesinin ortasında sur temel yatakları ve taş kesim izleri vardır. Savunulan bölge yani iç kale küçüktür; en fazla uzunluğu $155 \mathrm{~m}$ ve genişliği $30 \mathrm{~m}$ den $5 \mathrm{~m}$ 'ye değişen genişlikte bir alandır. Giriş kuzeydoğu taraftandır. Dış kapı surlarının ötesinde kayaların zirvesine doğru yönelen iç kapıya paralel bir rampa üzerinde uzanır. Ana savunma saldırılara açık olan kuzey kısmında odaklanmıştır (Crow 1996, 18).

Yapı, kurulduğu alanın arazi yapısına göre şekil almıştır. İç kale olarak adlandırılan kısımda birbirinden $10 \mathrm{~m}$ yükseklik fark ile iç içe iki müdafaa mevki oluşturulmuştur (Akok, 1945, s. 402). Burada büyük taşlarla yapılmış üç geniş dikdörtgen koruma kulesi vardır. Bu çizginin gerisinde iç savunmayı oluşturan biri yarım daire diğeri üçgen planlı iki kule vardır. Bu alanın geri kalanı çevresi taşlarla örtülmüş düzensiz kuleler ile savunulmaktadır. Zirvede tünel hariç tek ayakta kalan yapı iç kapının güneyinde bulunan sarnıçtır. Duvarlar Doğu Roma ve Türk kalelerin bilinen tarihinden beklenebilecek karmaşık bir yapıyı ortaya koyar. Bu büyük taş işçiliğinin en erken safhası, dörtgen burçlar Doğu Roma Dönemi'ne ait olabilirken tünel ise Doğu Roma öncesine ait olması gerekir (Belke 1996, 18).

Kalenin 1935 yılından önceki görüntüsüne göre kuzey kısımda kalın ve sağlam surlar, diğer kesimlerde de kuzey yönü kadar olmasa da sur ve burçlar görülebilmektedir (Yaman 1935, 63$65)$.

Kalenin yapım stili Doğu Roma Dönemi'ne tarihlenebilse de geri kalan bölüm kesin değildir. Bu büyük taş işlerinin kullanımı ile muhtemel bir benzerlik tahmini olarak MS VIII. yüzyıl Paphlagonia'sının büyük limanlarından olan Amastris'in yeniden inşasında görülebilir. Kastamonu'da bu kadar erken bir dönem olması beklenilmemektedir fakat aynı zamanda taş işleri erken Doğu Roma Dönemi'nin karakteristik özelliklerini taşımaktadır (MS VIII-IX. yüzyıllar). Paphlagonia'da ve Pontos'un diğer merkezi bölgelerinde sadece büyük ve önemli kalelerde bu görülmektedir (Crow 1996, 18). Keza Ankara Kalesi surlarının 859 tarihinde neredeyse tümünün yenilenmiş olduğu da bilinmektedir (Tanyeli 1987, 27; Crow 1996, 18-19).

Kastamonu Kalesi eğer MS VIII-IX. yüzyıla kadar geri çekilebilirse, bölgede tespit edilmiş olan ve kentin 20 km kuzey-batısındaki Molla Ahmet Kalesi, 45 km batısındaki Araç Kalesi ya da güneyde Çankırı'nın Karacaviran ve Kurşunlu'da tespit edilmiş kaleleri de aynı döneme tarihlenebilir (Crow 1996, 25). Yani bölge genelinde benzer zaman diliminde tahkimatl1 yerleşimler oluşturmak için geniş çaplı bir inşai faaliyet olduğu görülebilir. 


\section{Sehrin Surları}

Kastamonu'nun MS 10. yüzyıl sonu ve MS 11. yüzy1l başından itibaren bir kastron olarak yazılı kaynaklarda da görülmeye başlaması akla bu döneme ilişkin kalenin dışında bir de yerleşimin varlığını ve eğer böylesi bir yerleşim var idiyse bunun bir surla çevrili olup olmadığını akla getirmektedir.

$\mathrm{Bu}$ döneme ilişkin bir yerleşimin olduğu ya da kentsel nüvelerin ortaya çıktığına dair maalesef elimizde şu anda hiçbir bulgu bulunmamaktadır. Bunun nedenleri arasında ilk olarak, modern şehrin bu Ortaçağ yerleşimi üzerinde şekillenmiş olması, Komnenos Hanedanı'nın burayı kurmasından çok kısa bir süre sonra imparator olarak Konstantinopolis'e gitmesi, ayrıca 1084 itibarıyla Türklerin eline kati olarak geçeceği 1212 yılına kadar sürekli çatışma ortamının bölgede sürmesi ve sürekli el değiştirmelerin yanı sıra bölgede antik çağda olduğu gibi ahşap malzemenin yoğun olarak kullanılmış olabileceği sayılabilir.

Kentin bir sura sahip olup olmadığı ise tartışmaya açık bir konudur.

Khoniates, (5.26) bilgilerinde 1130 ya da 1132 yılındaki harekâtta John Komnenos'un Kastamonu'yu kuşatıp helepoleislerle ele geçirdiğini söyler. Aynı dönemde Theodora Prodramos'ta bu zaferleri öven şiirlerinde, imparatorun önce kenti kansız almak için teslim almaya zorlandığını ardından da büyük taşlar atan güçlü kuşatma makinelerini kullanarak şehri aldığını bildirir (Dennis 1998, 111-112). Bu ifadeler kastron olarak adlandırılan bir yerleşimin surlarla çevrili olduğu bilgisini vermektedir. Ancak bu surların, yukarıda belirtildiği gibi sadece iç kale ve onun yükseldiği kayalık alanı çeviren koruma alanı mı yoksa iç kalenin içinde olduğu bir yerleşimi mi çevirdiği belirsizdir (Fig. 9-11).

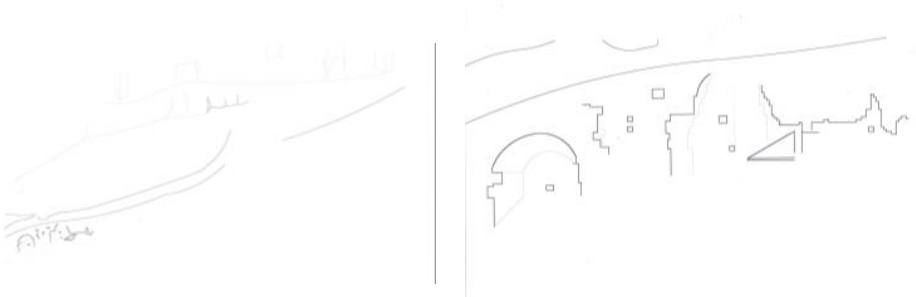

Fig. 9. Kale eski sur parçaları

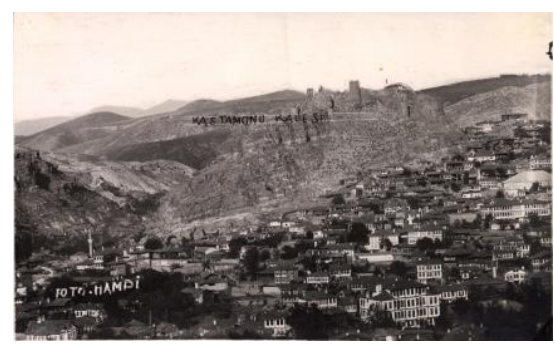

Fig. 11. Kale'nin zeminindeki tonozlu sur parçaları

Kastamonu için oldukça değerli bir isim olan ve Kastamonu Kütüphanesi Müdürlüğü de yapmış olan ve kente dair tüm Şerriye Sicillerini okumuş olan araştırmacı İhsan Ozanoğlu (1907-1981), 1958 yılında yazdığ bir gazete makalesinde surlar içindeki Kastamonu'yu şu şekilde ifade eder: Eski Kastamonu şöyle bir sur içinde idi: Kalenin cenubundan (güneyinden) bugünkü Vakıf Çarşısının şimal (kuzey) kesimini İbn-i Neccar Camii ve Vakıf Hamamını içine alarak Kuruçay istikametinde şarka (doğu) doğru Dede Çayın bugünkü şehir çayına uzanan dış sur, çay kenarından Nasrullah köprüsünü dışarıda bırakarak İzbeli Sokağa girer. Oradan Kale Kapısı dediğimiz mahalleye çıkardı. Halen Bozokluoğlu'na ait bahçenin şimal duvarı kale surundan bakiyedir. Buradan Gökdere istikametince devam eden sur, Püre Mahallesi ile Honsalar ve Gökdere Mahallelerinin yarısını dışarıda birakarak Inci Tepesine ve oradan da Hendek mevkiinin üstünden klvrllarak iç kaleye müntehi olurdu. Işste Eski Kastamonu şehri bundan ibaretti. Bu surdan başka, iç kaleye "hali hazırdaki kale bakiyesine" kadar altı sur daha vardl. Bu sur içinde Orta Köy denilen Nasrullah mevkiinden itibaren çarşılar ve mahalleler devam ederdi (Ozanoğlu 1958, Yeni Kastamonu, 24 Temmuz 1958).

İzleri 18. yüzyılda silinmiş olan surların varlığı genel anlamda kabul görürken bu surların güzergâhının ise şu şekilde olduğu düşünülmektedir. Surlar, İbn-İ Neccar Camisi, Vakıf Hamamı ve Sinan Bey Camisini içine alacak şekilde güneyde yani Gümüşlük Deresi sınırı ile 
batıya inip, Karaçomak Deresi boyunca kuzeye devam eder. Surların kuzeye yönelişinde bugün ki Nasrullah Cami ve Nasrullah Köprüsü civarında bir kapıya sahip olduğu 1139 (1723) tarihli şerriye sicilinde sur ve kapının hala mevcut olduğu da yazmaktadır (Gökoğlu 1952, 172). Şeriyye Sicilinde kapının mevcudiyeti "Medine-i Kastamonide vaki Nasrullah cisri başında olan kale divarı kapusu mürûr-u eyyam ile harab ve viran ve kapusunda olan dimur çıbıkları hurda olub zayi olmağla zikr olunan kanunun dimur çıbıları füruht olunub bir hayrata sarf olunmasını ehl-i vilayet makûl ve münasib görmeleri ile..." şeklinde geçmektedir (Ozanoğlu, 1955, Defter No: 610, H. 1139). Şeriyye Sicillerinde, kent merkezindeki Topçuoğlu, Bedirgazi, Püre, Arabapazarı Mahallerindeki ev ya da arsalara ait dava dosyalarında "kale suru" ifadelerine de rastlanmaktadır. (Ozanoğlu, 1955, D. 423-413, 31 - H. 1115; D. 425-415, 147 - H. 1119; D. 426-416, 90 - H. 1118; D. 438-428, 47- H. 1138; D. 463-453, 505 - H. 1179; D. 464-454, 332 H. 1108; D. 464-454, 358 - H. 1181; D. 470-460, 3351- H. 1190; D. 473-463, 376 - H. 1198; D. 499-89, 21 - H. 1231).

Surlar, bugünkü Belediye Caddesi’nin dereye bağlandığı noktaya kadar kesintisiz devam etmiş olmalıdır. Buradan tekrar batıya yönelen surlar (İzbeli Sokak), Arabapazarı Caddesi'ne kadar uzanmıştır. Bu bölgenin kuzeyinde yer alan ve Arabapazarı Caddesi ile birleşen Kalekapısı Sokak kesişme noktasında bir sur kapısı olduğunu göstermektedir. Tekrar güneye yönelen surların Çatlakkapı Sokak'ın Arabapazarı ve Kefeli Sokak ile birleştiği yere gelince, Abdülhak Hamit İlkokulu'nun yanından batıya devam etmesi, eğim çizgileri dikkate alındığında en uygunu olarak görülmektedir. Yukarıpazar Sokak adını taşıyan bugünkü yolu takip ederek Hamza Ağa Camisinin önüne çıkan surun, yeniden güneye dönüp, Kalearkası Sokak üzerinden dik yamaca saplanmasıyla yaklaşık 30 hektarlık alanı kapsayan sur içi tamamlanmış olur (Gökoğlu 1952, 172; Eyüpgiller 1999, 55). Dış surların Hamza Ağa Camisinin yer aldığı noktada bir kapısının bulunması ve Osmanlı Döneminde "Yukarıpazar" adıyla anılması bu bölgenin, Doğu Roma Dönemi’nde de Pazar yeri olması olası görülmektedir (Eyüpgiller 1999, 55).

Mevcut yazılı kaynaklar ve Kastamonu'nun tarihsel merkezindeki sokak yapısına göre modellenen sura ait olabileceğini düşündüğümüz bir parça, kentte hala Kale Kapısı (İ. Ozanoğlu'nun Bozokoğlu'na ait bahçenin kuzey duvarı diye tarif ettiği) olarak adlandırılan ve tarihsel kaynaklara göre de surlu kentin kuzey kapısı olabilecek bir noktadaki tonozlu bir yap1 bulunmaktadır. Yapı kentsel sit alanı içindeki, Topçuoğlu Mahallesi, 339 Ada 2 Parsel de yer alır.

Sur parçası ya da kentin kuzey kale kapısına ait olabilecek bu parça, İzbeli Sokak ile Kale Kapısı sokağın birleşim noktasına yakın bir şekilde kuzeybatı-güneydoğu istikametinde uzanmaktadır. Kuzeydoğu ve güneybatı uçlarında birer ev ile sınırlandırılmış, kuzey kısmı sokağa güneyi ise bir bahçeyi kapatmaktadır. Sur parçasının yaklaşık ölçüleri 7-4 m arasında yükseklikte, $10 \mathrm{~m}$ uzunluk ve $10 \mathrm{~m}$ genişliktedir. Sur dış duvarı daha küçük kireç taşları ile özensiz bir biçimde oluşturulmuştur. Muhtemelen surun yapımından sonraki dönemlerde günümüze kadar uğradığı tahribattan dolayı özensiz bir örgü ile yenilenmiş olmalıdır.

Duvarın iç örgüsü yaklaşık 50-60 cm yükseklikte çok iri olmayan ve düzenli olmayan kireçtaşları ile subasman oluşturulmuştur. Bunun üzeri oldukça düzgün $50 \times 40 \mathrm{~cm}$ boyutlarda kireçtaşı bloklarla örülmüştür. Blokların arasındaki derzlerde küçük taş katkılı kireç harç kullanılmıştır. Surun korunmuş en yüksek noktası 7 m'dir.

Sur yapısının bahçe tarafına bakan yüzünde, ortada kemerli bir kapı ile girilen tonozlu bir odası bulunmaktadır. Oda ölçüleri $7 \mathrm{~m}$ uzunluk $4 \mathrm{~m}$ genişlik ve 3 yüksekliktedir. Güney yüz üzerinde subasman üzerine oturtulmuş oldukça düzenli bir kesimli işlenmiş taş işçiliği ile örülmüş kireçtaşı bloklarla örülmüş bir duvardır. Altta subasman kısmı daha düzensiz az işlenmiş taşlar ve kaba kireç ile taşçık katkılı harç ile örülmüş, buradan ana sur duvarına geçiş 
ince ve yassı taşlarla sağlanmıştır. Yan duvarlar 1 metre kadar taşlarla çıkıldıktan sonra tuğla örgü ile hazırlanan tonoz, üzeri kireç ve kalın taşçık katkılı bir sıva ile kaplanmıştır. Görüldüğü kadarıyla tonozlu yapıda özenli bir işçilik görülmemektedir. Tonoz ve duvarlarda ahşap hatıllar görülebilmektedir (Fig. 12-18).

Mevcudu tahmin edilen surun şehrin güney sinırında olan Eligüzel Cami'den başlayıp Atabey Sokağı'nı takip eden Belediye'ye (Eski Belediye) ve Çarşı'ya (Nasrullah Cami ve çevresinde tarihsel-ticari alan) ulaşan yolun kentin güney ve kuzey kapılarını birleştiren yol olma ihtimali vardır. Keza Atabey Sokă̆ı'nın güney bitiminde daha önce tespit edilen ancak günümüze ulaşmayan bir duvar kalıntısının da Doğu Roma Dönemi suruna ait olabileceği bildirilmiştir (Kuban 1967, 6; Tanyeli 1987, 52). Ancak kentin yüzyıl başına ait fotoğraflarında kalenin batı yamaçlarında ve günümüzde Eli Güzel Cami'nin bulunduğu noktadaki sur izleri takip edilebilmektedir. Bu sur kalıntıları, iki geniş tonoz şeklinde görülmekte ve iç kalenin en alt sınırını oluşturan burç sistemleri olduğunu düşündürmektedir.

$\mathrm{Bu}$ surun varlığı kabul edilirse, karşımıza surun ne zaman

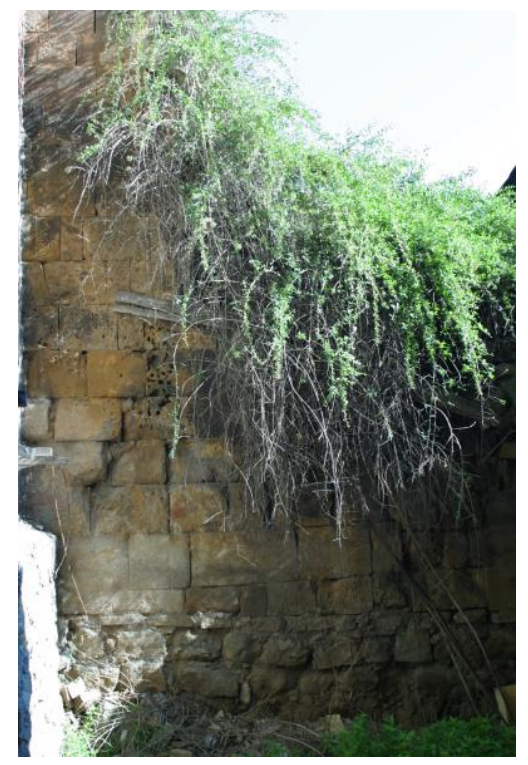

Fig. 12. Tonozlu Sur parçası yapıldığı sorusu çıkacaktır. İlk olarak, Ahrweiler'in işaret ettiği gibi IX. yüzyılda Kastamonu'nun bir yerleşim ya da kastron olma sürecinde kale ve surlar oluşmaya başlamış mıdır? Keza, kalenin kuzeyindeki örgü sisteminin 8-9 yüzyıla işaret ettiği de belirtilmiştir. İkinci olarak, 11. yüzyıl başlarından itibaren Komnenosların kente yerleşmesi ve kale yapım sürecinde dış surları da yapmış mıdır? Ya da bu süreç Kastamon'un özellikle Türkler ve Doğu Romalılar ile el değiştirmeleri sırasında ve hatta hemen akabinde ilk Türk yerleşimi sırasında da devam eden ve genişleyen bir durum mudur? Keza bu durum iki tarafın sık sık el değiştirmesi nedeniyle mümkün görülmemektedir. Yani kale ve surların en geç 11. yüzyılda yapılmış olması gerekmektedir.

Komnenoslar dönemi ve 13. yüzyılın başlarına kadar olan sürece ait kale ve olası sur parçası ya da sur kapısı parçasından başka mimari bir kalıntının korunmamış olması bize bu dönem kenti hakkında pek de konuşma imkânı tanımamaktadır. Bu durum birçok araştırmacı tarafından Kastamon'un bu dönemde bir kale kentten çok askeri bir garnizon yerleşimi gibi algılanmasina neden olmuştur. Ancak öte yandan varlığı düşünülen surların 30 hektar gibi bir alanı kapsiyor olması da burada bir kentsel yerleşimin varlığı olması gerektiğini düşündürür. Yukarıda

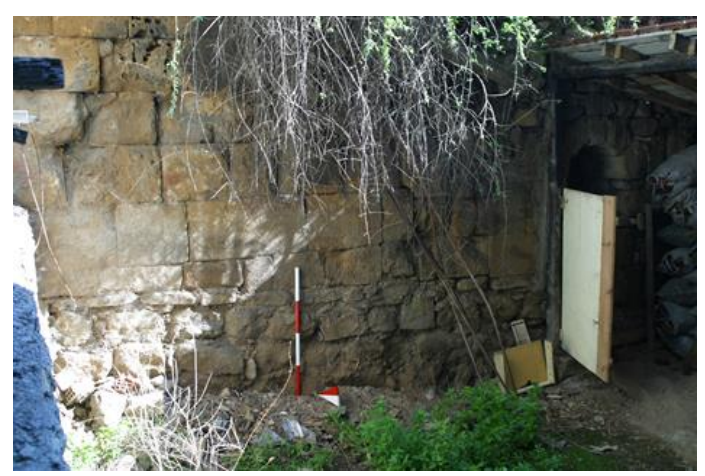

Fig.13 Tonozlu Sur parçası da değindiğimiz gibi, 12. yüzyılın başından itibaren çeşitli kuşatmalarla el değiştirmelerin tahribat1, bu savaşlar süresince imar hareketinin olmayışı belki de günümüze ulaşabilecek önemli bir yapının yapılmasını imkânsız kılmış ve günlük ihtiyaçlara cevap verecek konut ve basit kamu yapıları ile hayat sürdürülmüştür (Fig. 19).

Kastamon'daki yerleşime dair belki de bir cevap yine bir Doğu Romalı tarihçiden gelebilir. Osmanlı Padişahı I. Beyazıd'ın (1389-1402) Candaroğulları üzerine yaptığı savaşta Osmanlı ordusunda vassal olarak bulunan Manuel II Palaiologos'un, Kydones adlı birine yazdığı mektup 
bize bu konuda fikir verebilir. Palaiologos, Manuel Komnenos'tan iki yüzyıl sonra bu toprakların hazinli, nüfusun olmadığı, Amnias Vadisi’nde ne zamandan kaldığı belli olmayan kalıntılar şeklinde bir tarifini yapar ve Sinop'a yürüyüşlerinde muhtemelen Kastamon'dan geçerken Türkmenlere sorduğu soru karşısında "biz onu yok ettik, zaman da onun ismini yok etti" cevabını aldıktan sonra Pompeiopolis'in y1kıntılarından bahseder (Manuel Palaiologos Letter 16, 4244).

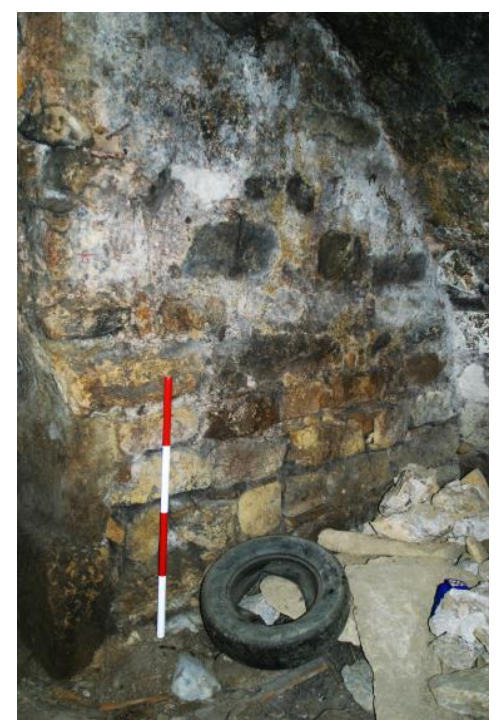

Fig. 14. Tonozlu Sur parçası

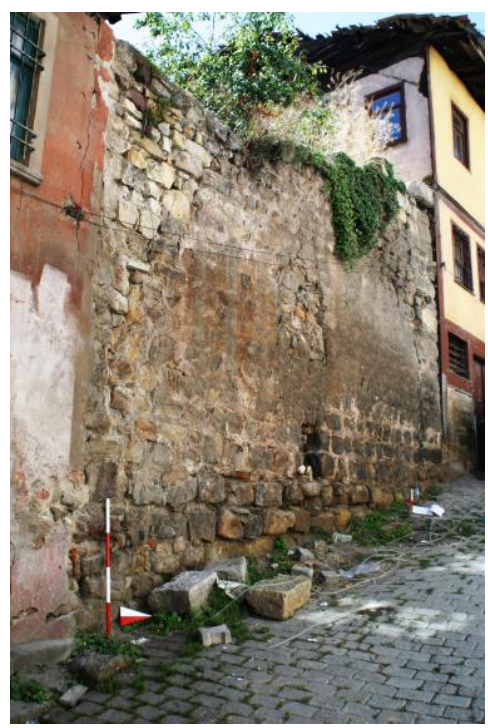

Fig. 15. Tonozlu Sur parçası

\section{Türk Hâkimiyetinden Sonra Kastamonu}

Çalışmamız bitim sınırı Türk Hâkimiyeti olmasına karşın, Kastamonu'ya bu dönemde imar faaliyetleri ve yapıların konumlanması bir noktada Doğu Roma Dönemi Kastamonu'nun yerleşimi konusunda bize fikir verdiğinden bu inceleme içine alınmıştır.

Kastamonu'nun kati olarak Türk Hâkimiyetine geçmesi 1212 yılı ile başlatılır. Selçuklu Melikü'-ümarası (Cahen 2008, 187) Hüsameddin Çoban Bey, Kastamonu beyi olarak ilk kez İbn Bibi'nin bu tarihe ilişkin kayıtlarında görülür (Yücel 1988, 36). Kentin 1212 yılında ele geçmesine karşın, ilk yapıların 13. yüzyılın ikinci yarısında ve hatta yüzyılın üçüncü çeyreğinde yapılmaya başlandığı görülür. Bu yapılardan günümüze ulaşan Frenkşah Hamamı 1262 yılında, etrafındaki 9 dükkânla birlikte yine Frenkşah tarafından yaptırılan mescit ve türbeye vakfedilmiştir (Behçet 1925, 124-133; Bilici 1991, 136-139). Hamam bugün Nasrullah Meydanı'nda, Nasrullah Cami'nin kuzey batısında yer alır ve surlu kentin içinde güney kapısına en yakın noktada bulunur. Diğer yapı ise günümüzde Yılanlı Cami olarak bilinen Pervane Muinüddin Süleyman Din Ali Darüşşifası 1272 yılında Frenkşah Hamamı'nın biraz güneyine yapılmıştır (Behçet 1925, 48; Bilici 1991, 107-115). Bu yapıda surlu kentin içinde kalenin eteklerinin son bulduğu düzlükte şehrin doğu kapısına oldukça yakın yapılmışlardır ve kentin Türk dönemi ilk kamu yapıları olarak bilinirler (Kuban 1967, 7).

$\mathrm{Bu}$ iki yapı ve konumuna bakarak, surlu kenti ikiye ayıran güneyde Eligüzel Cami'den başlayıp kuzeyde Kalekapısı mevkiine ulaşan ve kenti güneyden-kuzeye geçerek kentin kap1larına ulaşan ana yolun hemen kenarında yer almaları ve hem kamu yapıları hem de ticaret mekânlarıyla bir şehir merkezi ya da çarşı oluşturmaları bir noktada Doğu Roma'dan devir alınan ana arterleri üzerinden kentin şehir merkezi ya da pazarının devam ettiği görülebilir (Tanyeli 1987, 53). 


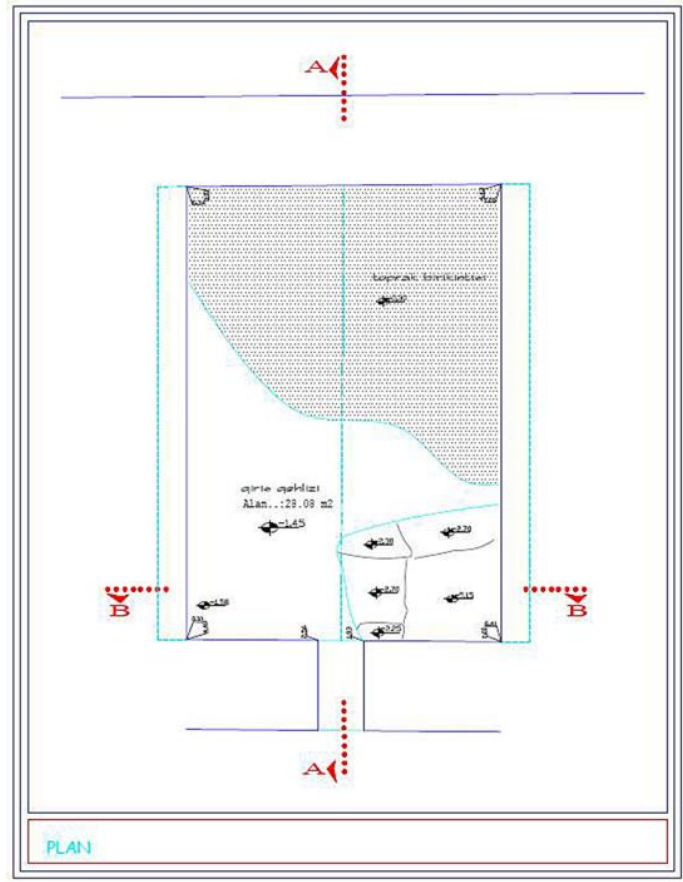

Fig. 16. Tonozlu sur parçası

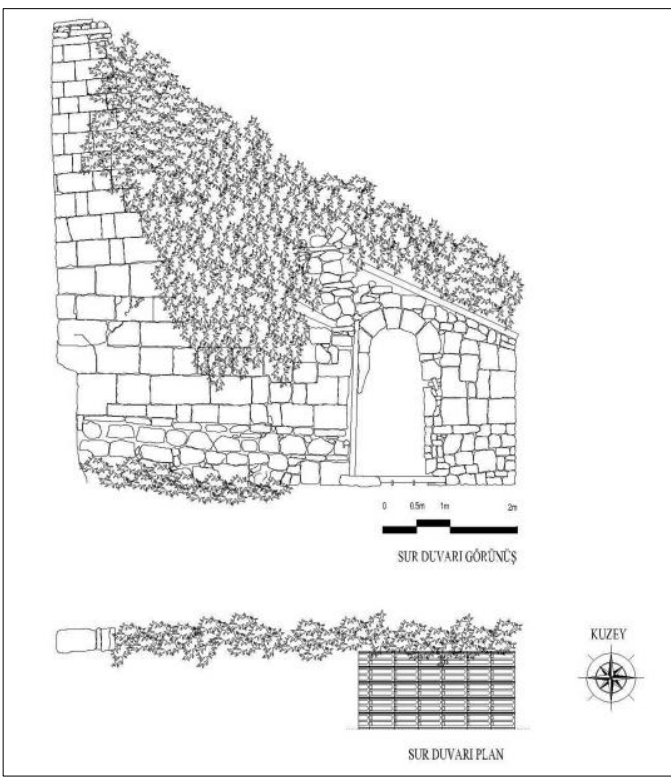

Fig. 18. Sur duvar1

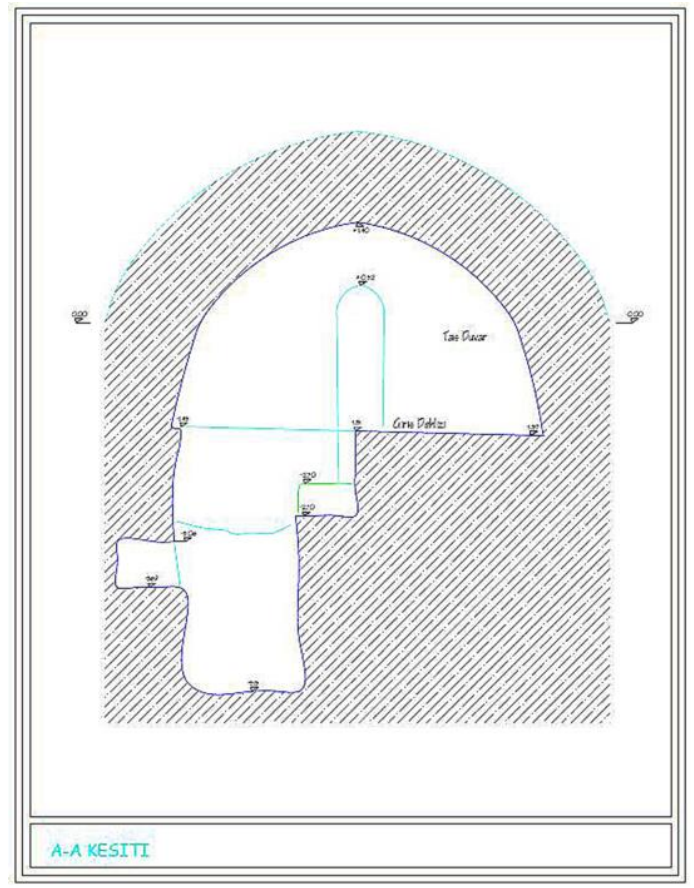

Fig. 17. Tonozlu yapı kesit

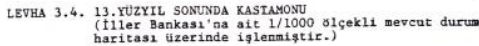

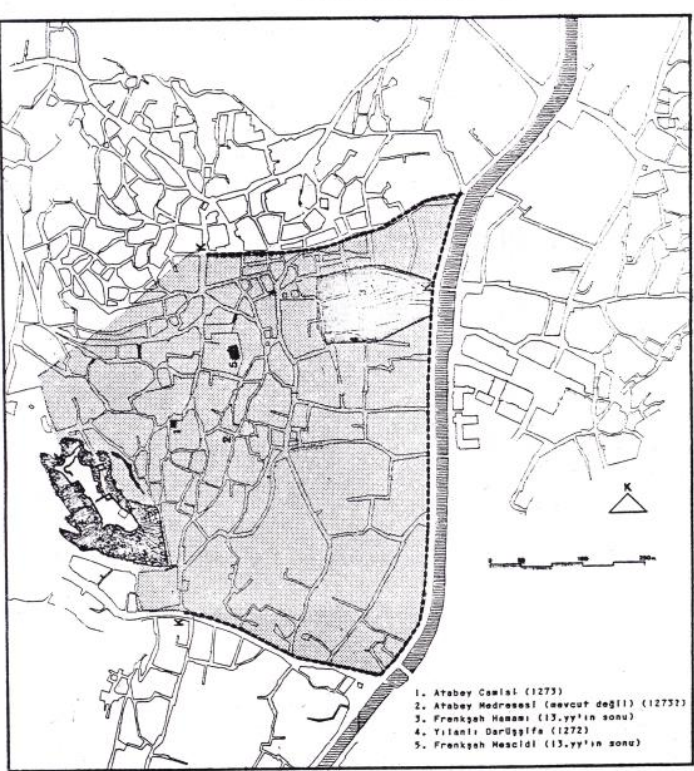

Fig. 19. Tanyeli-levha-3

\section{Sonuç}

Kastamonu il merkezi ve içinde bulunduğu bölge olan antik Paphlagonia Bölgesi, arkeolojik anlamda araştırma azlığı, antikçağ kaynaklarının yeterli bilgi vermemesi gibi nedenlerden dolayı hala birçok soruyu bünyesinde barındırır. Bu sorular bölge kadar çalışmamızın ana konusu olan Kastamonu kent merkezini de içermektedir. Ancak mevcut veriler 1şı ğında Kastamonu kentinin kültürel katmanlaşmasının Orta Paleolitik Çağ’da başlayıp, günümüze kadar sürdüğü görülmektedir. 
Çalışmamız kapsamında ele alınan buluntuların Paleolitik Çağ'dan İlk Tunç Çağı'na kadar kentin çok yakınından gelmesi bu tarihten itibaren de kent merkezinden geliyor olması Kastamonu kent merkezinin insanla tanıştığı dönemden itibaren bir iskân yeri olduğunu göstermektedir. Elbette veriler, erken dönemler için yerleşimin nasıl seyrettiğini vermemektedir.

Bir yerleşim olarak Kastamonu'ya dair konuşulabilecek en erken dönem MÖ I. Bin ortaları ile başlar. Bu döneme ait özellikle dinsel kaya mimarisinin yoğunluğu ve özelliklerine bakarak dönemin bölge içindeki önemli bir yerleşim yeri olduğu doğrultusundadır.

Hem kent merkezindeki dinsel kaya mimarisi hem de bölgedeki diğer kaya mezarlarının incelemesinde bu mezarların dönem yerleşimlerinin bir parçası olduğu tespit edilmiştir. Bu kaya mezarlarının bulunduğu kayalık alanların da yerleşim alanları olduğu görülmüştür. Bu noktada Kastamonu kent merkezinde hem Ev Kaya Mezarı'nın bulunduğu nekropolis alanının çevresi hem de kale yamaçlarındaki kaya mezarı ve kaya tüneline de bakarak buranın da dönem yerleşim alanları olarak önemli bir Geç Demir Çağı merkezi olduğu söylenebilir.

Yine mevcut buluntulara göre Hellenistik Dönem ve sonrasında yerleşim ağırlığ Kastamonu'nun doğusunda akarsularla parçalanmış vadilerde yoğunlaştığı görülmektedir. Bu döneme ilişkin Kastamonu ve yakınını işaret eden epigrafik veri yoktur.

MS III. yüzyıl ile başlayan ve MS VII-IX. yüzyıl aralığında yoğunlaşarak devam eden akınlar bölgede yerleşim tipolojisini değiştirmiş, bu değişimle açik yerleşimler, bulundukları yerlerden taşınarak daha yüksekte ve korunaklı alanlara intikal etmiş ve burada tahkimatlı yerleşimler halini almıştır. İşte böylesi bir değişimde Kastamonu; Geç Demir Çağı'nda olduğu gibi yeniden bir merkez haline gelmeye başlamış ve tahkimatlı bir yerleşim olarak yeniden vücut bulmuştur. Kale duvarlarının örgü sistemine göre MS IX. yüzyıla kadar geri giden tahkimat sistemi ile kastrona dönüştüğü düşünülen yerleşimde, Komnenos Sülalesi'nin bölgeye yerleşmesi ile kale kent özelliği tam olarak ortaya çıkmış ve 11. yüzyılda bölgenin en önemli yerleşimi olarak ortaya çıkmıştır.

$\mathrm{Bu}$ süreçte birkaç önemli soru ortaya çıkmaktadır. Bunlardan ilki, bir kastron olarak yeniden ortaya çıkan Kastamon'un surlarının varlığı ve bu surların varlığı kabul edilirse yerleşimin bir askeri nüveden çok şehir kimliğine sahip olup olmadığıdır. Eğer surların çalışmada gösterilmeye çalışıldığı gibi varlığı kabul edilir ve bu surların 30 hektar gibi geniş bir alanı koruduğu düşünülürse burada bir dönem önemli bir nüfusun yaşadığı düşünülebilir. Kale ve surların oluşturulma tarihi 11. yüzyıl olarak kabul edilecek olursa, bu dönemden günümüze bir kalıntı ya da buluntu ulaşmamasının nedeni olarak 13. yüzyıl başlarına dek sürecek olan el değiştirmeler ve bunun sonucu olan istikrarsizlık olarak görülebilir.

Son söz olarak Kastamonu İl merkezinin özellikle bugün gördüğümüz fiziksel iskeletinin temelini 13. yüzyılın ikinci yarısı ile oluşmaya başladığı bilinse de bu iskeletin yine Doğu Roma Dönemi oluşan kastronu takip ettiği de görülebilir. Çağlar içinde bakıldığında mevcut kalıntılara göre Kastamonu kent merkezinin ilki Geç Demir Çağı, ikinci olarak IX-XI. yüzyıllar sürecinde ve son olarak da 13. yüzyılın ikinci yarısıyla bölgede önemli bir yerleşim merkezi olarak var olduğu, kültürel katmanlaşmasını da Orta Tunç Çağı'ndan itibaren oluşturduğu ve neredeyse kesintisiz sürdürdüğü görülür. 


\section{Antik Kaynaklar}

\section{KAYNAKÇA}

Attaleiates M., The History. Trans. A. Kaldallis-D. Krallis, Harward Universty Press. London 2012.

Bryennios Nikephoros, Tarihin Özü. Çev. B. Umar. İstanbul 2008.

Diod. Sic. (= Diodorus Sicillus, Bibliotheke Historike) Trans. R. M. Geer, London, New York 1947 (Loeb).

Const. Proph. De Adm. Imp. (= Constantinus Porphyrogenitus, De Thematibus et de Admintranto Imperio). Trans. I. Bekkerus. Bonn 1840.

Hdt. (=Herodotos Historia). Çev. M. Öktem, İstanbul $1991^{3}$.

Hom. (=Homeros İlyada) Çev. A. Erhat. İstanbul 1993.

Khoniates, Niketas Khoniates, Historia (Ioannes ve Manuel Komnenos Devirleri). Çev. F. Işıltan. Ankara 1995.

Khoniatae, Niketae Historia. Trans. I. Bekker, Bonn 1835.

Kinnamos, Ioannes Kinnamos'un Historia'sl. Yay. Haz. I. Demirkent. Ankara 2001.

Cinnamus, Ioannis, Epitome Rerum ab Ionne et Alexio Comnenis Gestrum. Trans. A. Meieke. Bonn 1836. Anna Komnena, Aleksiad. Çev. B. Umar. İstanbul 2008.

Manuel II Palaeologos, Letters, The letters of Manuel II Palaeologos. Trans G.T. Dennis. Dumbarton Oaks Texts IV 1977.

Strab. (=Strabon, Geographika) Antik Anadolu Coğrafyası, Çev. A. Pekman, 1993.

Plut. (= Plutarchus, Iside et Osiride 69). Trans. William W. Goodwin. Cambridge 1894.

Psellos, M. Chronographia. Trans. E. R. A. Sewter. Yale Universty Press 1953.

Zos. (= Zosimus Historia Nova). Çev. W. Green-T. Chaplin. London 2005.

\section{Modern Kaynaklar}

Akok, M. (1945). “Kastamonu Şehri Tarihi İç Kalesi”. Belleten 35 (1945) 401-407.

Akurgal, E. (1955). Phrygische Kunst. Ankara: Archäologisches Institut der Universität, Ankara 1955.

Ahrweiler, H. (1962). "L'Asie mineure et les invasions arabes (VII'- IX' siecle)". Revue Historique CCXXVII (1962) 1-32.

Arslan, M. (2007). Mithradates VI Eupator Roma'nın Büyük Düşmanı. İstanbul 2007.

Behçet, M. (1925). Kastamonu Asar-ı Kadimesi. Yay. Haz. M. S. Cihangir. Kastamonu 1998.

Belke, K. (1996) Tabula Imperii Byzantini, 9. Paphlagonien Und Honorias. Wien 1996.

Berndt-Ersöz, S. (2006). Phrygian rock-cut shrines; structure, function, and cult practice. Leiden 2006.

Bilici, K. (1991). Kastamonu’da Türk Devri Mimarisi ve Şehir Dokusunun Gelişim. Ankara Üniversitesi Sosyal Bilimler Enstitüsü, Yayımlanmamış Doktora Tezi. Ankara 1991

Bittel, K. \& R. Naumann. (1965) "Notizen über einige paphlagonische Felsgräber". Anadolu Araştırmaları 2/1-2 (1965) 71-84, pls. 8-13.

Brüggemann, T. (2012). "Paphlagonia Between Goths, Sasanides and Arabs (MS 3rd-8th AD)". Ed. G.R. Tsetskladze. The Black Sea, Paphlagonia, Pontus and Phrygia in Antiquity. (2012) 45-52.

Bryer, A. \& Winfield, D., (1985). The Byzantine Monuments and Topography of the Pontos, Vol. I. Dumbarton Oaks, 1985.

Bostancı, E. Y. (1952). "Gök Irmak Vadisinde Prehistuvar Araştırmaları Yeni Paleolitik Buluntular”. A. Ü. DTCF Dergisi X/1-2 (1952) 37-42.

Burney, C. A. (1956). "Northern Anatolia Before Classical Times". Anatolian Studies 6 (1956) 179-203.

Casis, M. (2015). "The Cide-Şenpazar Region in the Byzantine Period". Eds. Düring, B., Glatz. C. Kinetic Landscape The Cide Archaeological Project: Surveying the Turkish Western Black Sea Region. Warshaw (2015) 294-363.

Chalandon, F. (1912). “Les Comnene”. Etudes sur L'empire Byzantin aux XIle et XIIle Siecles, II (1912) 82-91.

Cahen, C. (2008). Osmanlılardan Önce Anadolu. Çev. E. Üyepazarcı. İstanbul $2008^{3}$.

Crow, J. (1996). "Alekxios Komnenos and Kastamon: castles and settlement in middle Byzantie Paphlagonia”. Eds. M. Mullet-D. Smythe. Alexios I Komnenos Kolloquium Belfast 1989. Belfast (1996) 12-36.

Dennis, G. T. (1998). “Byzantine Heavy Artillery: The Helepolis”. Greek, Roman, Byzantine Studies 39 (1998) 99-115.

Donceel-Voûte, (1979). "Gökırmak Valley, 1977 (Recent archaeological research in Turkey)". Anatolian Studies 29 (1979) 196-97.

Donceel-Voute (1983). "Un banquet funéraire perse en Paphlagonie”. Eds. R. Donceel \& R. Lebrun. Archéologie et religionsde l'Anatolie ancienne; mélanges en l'honneur du professeur Paul Naster. 
Louvain-la-Neuve: Centre d'Histoire des Religions (1983) 101-118.

Dökü, F. E. (2008). Paphlagonia Bölgesi Kaya Mezarları ve Kaya Tapınakları. Akdeniz Üniversitesi, Sosyal Bilimler Enstitüsü Yayımlanmamış Doktora Tezi, Antalya 2008.

Dökü, F. E. (2017). "Batı Karadeniz Bölgesi’nde Pers İzleri”. Eds. K. İren \& N. Tekdemir. Persler, Anadolu'da Kudret ve Görkem. İstanbul (2017) 368-389.

Dukas (1956). Bizans Tarihi. Çev. L Mirmiroğlu. İstanbul 1956.

Durugönül, S. (1994). "Grabstele eines "Adligen" aus Paphlagonien der dritten Satrapie". Ed. E. Schwertheim. Forschungen in Galatien. Bonn (1994) 1-14, pls. 1-3.

Emre, K. - Çınaroğlu, A. (1993) “A Group of Metal Hittite Vessels From Kınık Kastamonu”. Studies in Honor of Nimet Özgüç (1993) 675-713.

Eyüpgiller, K. K. (1999). Bir Kent Tarihi Kastamonu. İstanbul 1999.

Foss, C.F.W, (1991). "Kastamon” The Oxford Dictionary of Byzantium, Vol II. Ed. A. Kazhdan, Oxford (1991) 1110.

Glatz, C. (2015a). "The Later Prehistory of the Cide-Şenpazar Region: ca. 2600-2000 BC". Eds. Düring, B., Glatz. C. Kinetic Landscape The Cide Archaeological Project: Surveying the Turkish Western Black Sea Region. Warshaw (2015) 151-182.

Glatz, C. (2015b). "Beyond the Frontier: The Second Millennium BC in the Cide-Şenpazar Region". Eds. Düring, B., Glatz. C. Kinetic Landscape The Cide Archaeological Project: Surveying the Turkish Western Black Sea Region. Warshaw (2015) 183-211.

Gökoğlu, A. (1952). Paphlagonia (Paflagonya); Gayri Menkul Eski Eserleri ve Arkeolojisi. Kastamonu 1952.

Harris, S. R. (1993). "UEA Spleogical Expedition Northern Turkey: August/September 1992". FACC (1993) 24-27.

Hirschfeld, G. (1883). "Notes of Travel in Paphlagonia and Galatia". The Journal of Hellenic Studies 4 (1883) 275- 280.

Hirschfeld, G. (1885) Paphlagonische Felsengräber. 1885.

Honigman, E. (1970) Bizans Devleti'nin Doğu Sinırı. Çev. F. Işsıltan. İstanbul 1970.

Jacopi, G. (1936), Dalla Paflagonia alla Commagene. Rome 1936.

Jacopi, G. (1937), Esplorazioni e Studi in Paflagonia e Cappadocia. Rome 1937.

Johnson, P. (2010). Landscapes of Achaemenid Paphlagonia. Unpublished Doctoral Dissertation in Art and Archaeology of the Mediterranean World Presented to the Faculties of the University of Pennsylvania. Pennsylvania 2010.

Karasalihoğlu, M. (2008). "Kastamonu Merkezli Paphlagonia Kaya Mezarları". Üsküdar'a Kadar Kastamonu. İstanbul (2008) 55-70.

Karasalihoğlu, M. (2012). "Kuzeybatı Anadolu Beyliklerinin Eser ve Yerleşimlerindeki Antik Çağ Bağlantıları". Kuzeybatı Anadolu Beylikleri Sempozyumu Bildirileri. Kastamonu (2012) 440-479.

Karasalihoğlu, M. (2015). "Paphlagonia'dan Kybele Açık Hava Kutsal Su Kompleksi". Arkeoloji ve Sanat Dergisi 149 (20159 55-76.

Karasalihoğlu, M. (2017). Antikçağ'dan Bugüne Glykon Kültüu. İstanbul 2017.

Kaygusuz, İ., (1984) . "Funerary Epigram of Karzene (Paphlagonia), A Girl Raped by the Goths?". Epigraphica Anatolica 4 (1984) 61-63.

Kazhdan, A. (1991). "Komnenos". The Oxford Dictionary of Byzantium, vol. II. Ed. A. Kazhdan. Oxford (1991) 1143-1144

Kökten, K. (1948) “1947 Yılı Tarih Öncesi Araştırmaları”. Belleten XII/45 (1948) 223-226.

Kökten, K. (1951). “Kuzeybatı Anadolu'nun Tarihöncesi Hakkında Yeni Gözlemler”. Ankara Üniversitesi DTCF Dergisi IX/3 (1951) 201-214.

Kuban, D. (1967). Kastamonu'nun Tarihi Yapısı ve Bu Yapının Imar Planında Değerlendirmesiyle Ilgili Bir Rapor. İstanbul 1967.

Kursanskis, Michel. (1977). "L'empire de Trébizonde et la Géorgie”. Revue des Études Byzantines 35 (1977) 237-256.

Laflı, E. (2007). "A Roman rock-cut cult niche at Paphlagonian Hadrianoupolis". AST 24 (2007) 43-66.

Laiou, E. A. (2009). "Family Structure and Transmission of Property". Ed. J. Haldon. A Social History of Byzantium. Blackwell Puphlishing (2009) 51-75.

Leonhard, R. (1902). "Paphlagonische Denkmäler - Tumuli, Felsengräber, Befestigugen". Schlesische Gesellschaft für Vaterländische Cultur IV/190 (1902) 1-37.

Leonhard, R. (1915). Paphlagonia; Reisen und Forschungen im nörlichen Kleinasien. Berlin 1915.

Marek C. (1993). Stadt, Ära und Territorium in Pontus-Bithynia und Nord-Galatia. Wasmuth, Tübingen 1993. 
Marek C. (2003). Orbis Provinciarum. Pontus Et Bithynia. Die Römischen Provinzen İm Norden Kleinasiens. Mainz Am Rhein, Verlag Philipp Von Zabern 2003.

Naumann, F. (1983). Die Ikonographie der Kybele in der phrygischen und der griechischen Kunst. Tübingen: Wasmuth 1998.

Ozanoğlu, İ. (1955). Kastamonu Şer'iye Sicilleri İçin Sistematik Kılavuz. Kastamonu (Teksir) 1955.

Ozanoğlu, İ. (1958). "Tahtalı Çarşıdan Beton Çarşıya”. Yeni Kastamonu 246, 24 Temmuz, 1958.

Özdoğan, A., Marro, C. Tibet, A. (1997). "1995 Yılı Kastamonu Yüzey Araştırması”. AST XIV/2 (1997) 303-330.

Özdoğan, A., Marro, C. Tibet, A. Kuzucuoğlu, C. (1998). "Kastamonu Yüzey Araştırması 1996 Yı11 Çalışmaları". AST XV/2 (1998) 63-104.

Özdoğan A., C. Marro, Tibet, A. (1999). “Kastamonu Yüzey Araştırması 1997 Yılı Çalışmaları”. AST XVI/2 (1999). 219-244.

Özdoğan, A., Marro, C., Tibet, A., Kuzucuoğlu, C. (2000). "Kastamonu Yüzey Araştırması 1998 Yılı Çalışmaları". AST XVII/2 (2000) 41-56.

Yinanç, M. H. (1944). Selçuklular Devrinde Türkiye Tarihi I. İstanbul 2000.

Ruge, W. \& K. Bittel. (1949). "Paphlagonia”. RE 18/4 (1949) 2486-2550.

Runciman, S. (1951a). "A History of the Crusades, Vol I. The First Crusade and Foundation of the Kingdom of Jerusalem”. Camridge University Press, Cambridge 1951.

Runciman, S. (1951b). "A History of the Crusades, Vol II, The Kingdom of Jerusalem and the Frankish East, 1100-1187”. Cambridge Universty Press, Cambridge 1951.

Saprykin, S. (1991). "Пафлагоника". Thracia Pontica 4 (1991) 241-54,

Saprykin, S. (2009). "The Religion and Cult of the Pontic Kingdom: Political Aspect”. BSS-9 (2009) 249-276.

Sivas, T. T. (1999). Eskişehir-Afyonkarahisar-Kütahya Il Sınırları İçindeki Phryg Kaya Anıtları. T.C. Anadolu Üniversitesi Edebiyat Fakültesi Yayınları, Eskişehir 1999.

Şenyürek, M. S. (1944). “Anadolu’da Bulunan İki Yeni Paleolitiğe Dair Bir Not”, AÜ DTCF Dergisi II/2 (1944) 349-352.

Şerifoğlu, T. E, Düring, B., Glatz, C. (2012). "Cide ve Şenapazar, 2009-2010 Y1lı Arkeolojik Araştırmaları”. Belleten LXXVI/277 (2012) 719-747.

Şerifoğlu, T. E., Bakan, C. (2015). “The Cide Region During The Hellenistic Period”. Eds. Düring, B., Glatz. C. Kinetic Landscape The Cide Archaeological Project: Surveying the Turkish Western Black Sea Region. Warshaw (2015) 246-259.

Tanyeli, U. (1987). Anadolu-Türk Kentinde Fiziksel Yapının Evrimsel Süreci. İstanbul Teknik Üniversitesi, Fen Bilimleri Enstitüsü, Yayımlanmamış Doktora Tezi. İstanbul 1987.

Turan, O. (1968). Selçuklular Tarihi. İstanbul 1968.

Uçar, Ş. (2012). Arapların Anadolu Seferleri. İstanbul 2012.

Vassileva, M. (2012). "The Rock-Cut Monuments Of Phrygia, Paphlagonia and Thrace: A Comparatıve Overview". Ed. Gocha R. Tsetskhladze, The Black Sea, Paphlagonia, Pontus and Phrygia in Antiquity. BAR International Series 2432 (2012) 243-252.

von Gall, H. (1966). Die paphlagonischen Felsgräber; eine Studie zur kleinasiatischen Kunstgeschichte. Tübingen: Wasmuth 1966.

von Gall, H. (1989). “Zum Bildgehalt der graeco-persischen Grabstelen”. Anadolu/Anatolia 22 (1989) 143-65, pls. 1-3, figs. 1-3.

Woolley, sir L. (1921). From Kastamuni to Kedos, being a Record of Experiences of Prisoners of War in Turkey, 1916-1918. Oxford 1921.

Yaman, T. (1935). Kastamonu Tarihi, XV'inci Asrın Sonlarına Kadar Kastamonu. Kastamonu 1935.

Yücel, Y. (1991). Anadolu Beylikleri Hakkında Araştırmalar I, Çobanoğulları Beyliği - Candaroğulları Beyliği. Ankara 1991. 